UNIVERSIDADE DE SÃO PAULO

FACULDADE DE FILOSOFIA, LETRAS E CIÊNCIAS HUMANAS

DEPARTAMENTO DE CIÊNCIA POLÍTICA

PROGRAMA DE PÓS-GRADUAÇÃO EM CIÊNCIA POLÍTICA

O CONCEITO DE DIPLOMACIA PRESIDENCIAL:

O PAPEL DA PRESIDÊNCIA DA REPÚBLICA NA

FORMULAÇÃO DE POLÍTICA EXTERNA

Alessandra Falcão Preto

São Paulo

2006 
UNIVERSIDADE DE SÃO PAULO

FACULDADE DE FILOSOFIA, LETRAS E CIÊNCIAS HUMANAS

DEPARTAMENTO DE CIÊNCIA POLÍTICA

PROGRAMA DE PÓS-GRADUAÇÃO EM CIÊNCIA POLÍTICA

\section{O CONCEITO DE DIPLOMACIA PRESIDENCIAL: O PAPEL DA PRESIDÊNCIA DA REPÚBLICA NA FORMULAÇÃO DE POLÍTICA EXTERNA}

Alessandra Falcão Preto

Dissertação apresentada ao Programa de Pós-Graduação em Ciência Política, do Departamento de Ciência Política da Faculdade de Filosofia, Letras e Ciências Humanas da Universidade de São Paulo, para obtenção do título de Mestre em Ciência Política.

Orientadora: Profa. Dra. Elizabeth Balbachevsky

São Paulo

2006 
Ao meu querido Mauricio, por ter tornado este trabalho possível

$$
e
$$

aos meus pais, que me incentivaram e apoiaram desde o primário até a universidade, sem questionar as minhas escolhas 


\section{Agradecimentos}

Gostaria de agradecer as instituições e as pessoas que contribuíram, direta ou indiretamente, para a concretização desse trabalho.

À CAPES, pelo apoio financeiro concedido durante a realização dessa pesquisa e ao DCP-USP por todo auxílio, principalmente aos seus funcionários, Rai, Ana Maria, Vivi e Márcia. À Mila do NUPRI pela sua atenção.

A minha orientadora, Profa. Elizabeth Balbachevsky, pela orientação atenciosa e pela sua paciência.

Ao Prof. Rafael Villa, pelas aulas, conversas e comentários que forneceram uma contribuição essencial para a concretização desse trabalho.

À Profa. Janina Onuki, por ter acompanhado o meu trabalho desde a idéia inicial até a etapa final, fornecendo sugestões valiosas para a sua continuidade.

Ao Prof. Andrés Malamud, pelos comentários preciosos em relação a esse tema tão pouco abordado.

À Profa. Denilde Holzhacker pelas orientações em relação à análise de política externa e por sua prontidão em me receber.

Ao Prof. Bruno Ayllón, pelas indicações de material sobre o tema, e também pela sua atenção.

Aos colegas de departamento: Mônica e Vera pelos comentários, conversas e amizade, e por compartilharem comigo muitas angústias e felicidades da pós; a Ignácio, pela leitura e simpatia; a Gustavo, pelas informações valiosas e esclarecimentos dessa área tão fechada que é a Diplomacia; à Kellen, por termos dividido momentos difíceis da fase de ser estudante.

À Sabrina, pelo exemplo a ser seguido e ao colega Bruno, de RI, pela gentileza em compartilhar material e conhecimento.

A Germán e à Flávia pelo apoio no concurso de ingresso ao Mestrado.

Ao Prof. Afrânio Catani por ter sido o primeiro a acreditar na minha capacidade acadêmica e a me ajudar nos passos iniciais. E ao Prof. Marcos Ferreira dos Santos, por ter se mostrado sempre disponível para debater idéias em relação a minha vontade de fazer pesquisa.

Aos amigos Alê, Vê, Vera, Téo, Andréa O., Luis, Marcos, Márcia, Tânia, Andréa M., Rosi, Gabi e todos outros, pelas palavras amigas, pelo torcida e preocupação, e principalmente por terem acreditado em mim. 
A minha querida irmã, pelo exemplo de dedicação ao trabalho e pela amizade de sempre e a minha doce sobrinha, pelos seus sorrisos incentivadores. Ao meu pai, que desmistificou a idéia que "política é chato" e fez com que fosse um assunto natural dentro de casa, proporcionando o interesse e o debate sobre o tema. E a minha querida mãe, por ter fornecido todo o apoio necessário para eu poder estudar tranqüilamente e chegar onde estou, além de ter torcido e acreditado em mim. Aos meus avós, in memoriam, que sempre me apoiaram nos estudos. Ao meu tio Hélio, pelo exemplo na carreira acadêmica e a minha tia Rosa, pelo apoio familiar de sempre.

Ao Mauricio, pelo carinho e pelas constantes leituras e apoio. 


\section{Resumo}

Nos últimos anos o termo diplomacia presidencial tornou-se conhecido por todos devido a sua presença tanto na mídia, quanto nos meios acadêmicos e diplomáticos. O objetivo do presente trabalho é analisar o conceito de diplomacia presidencial no Brasil, cunhado por estudiosos para nomear a nova atitude - mais ativa - de alguns presidentes em política externa. Essa análise é importante para uma melhor compreensão da ação dos chefes de Executivo nacionais no cenário externo. Para isso, comparam-se publicações que abordam o conceito e aquelas que o definem, o que contribui para a compreensão do seu estatuto teórico. Além disso, confronta-se o conceito de diplomacia presidencial com outras abordagens que tratam da ação da Presidência da República na formulação de política externa.

Palavras-chave: diplomacia presidencial, Presidência da República, formulação de política externa, política externa, diplomacia.

\section{Abstract}

In recent years the term presidential diplomacy has become widely known due to its constant presence in the media, the academic and diplomatic circles. This paper aims to analyze the concept of presidential diplomacy in Brazil, coined by researchers to describe the new and more active attitude toward foreign policy of some presidents. This analysis is important to better understand the actions executed by the head of the Executive in the international arena. Publications that approached the concept and those that defined it were compared in order to contribute to the comprehension of its theoretical statute. Furthermore, the concept of presidential diplomacy was confronted with other approaches that deal with the direct intervention of the Chief-of-State in the formulation of foreign policy.

Keywords: presidential diplomacy, Presidency, foreign policy-making, foreign policy, diplomacy. 


\section{Sumário}

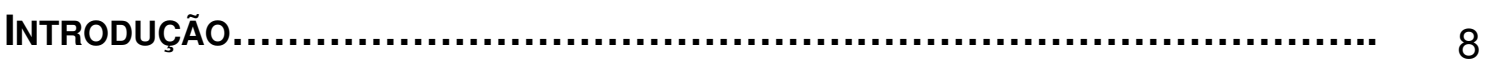

CAPÍtUlo 1-Principais atores na aRena de política externa BRASILEIRA ............................................................................................... 13

1.1 O PRESIDENCIALISMO ........................................................... 13

1.1.1 Especificidades do presidencialismo brasileiro .......................... 15

1.1.2 Atribuições constitucionais e características do presidente ............. 17

1.2 ALGUNS ASPECTOS DA POLÍTICA EXTERNA BRASILEIRA ............................. 18

1.3 ATRIBUIÇÕES CONSTITUCIONAIS E CARACTERÍSTICAS DO ITAMARATY ............ 23

CAPÍtUlO 2 - ANÁlise do CONCEITO De DiPlomacia Presidencial ................. 31

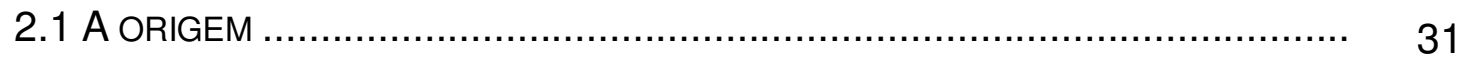

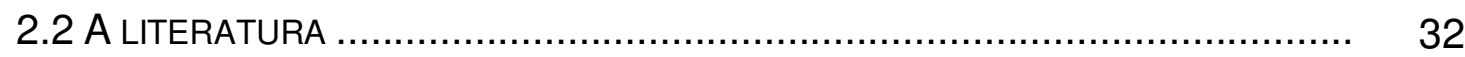

2.3 ANÁLISE COMPARATIVA DA LITERATURA ........................................ 52

CAPÍTULO 3 - A AÇÃo dO PRESIDENTE dA REPÚBLICA NO ÂMBITO DE POLÍTICA

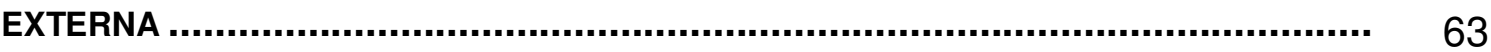

3.1 DIFERENTES ABORDAGENS TEÓRICAS .................................... 66

CAPÍTULO 4 - CONSIDERAÇÕES FINAIS ........................................ 84

REFERÊnCIAS BIBLIOGRÁfICAS ................................................. 96 


\section{INTRODUÇÃO}

Nos últimos anos o termo "diplomacia presidencial" tornou-se conhecido por todos, devido a sua presença tanto na mídia, quanto nos meios acadêmicos e diplomáticos. Mas afinal, o que é diplomacia presidencial? O senso comum a identifica, sem fundamentação, como sinônimo de viagens presidenciais. Muitas vezes essa abordagem teve uma qualificação negativa, pelo fato do chefe do Executivo se ausentar do país, o que foi entendido como omissão de autoridade em relação às suas responsabilidades de governo.

O objetivo do presente trabalho é analisar o conceito de diplomacia presidencial no Brasil, cunhado por estudiosos para nomear a nova atitude mais ativa - de alguns presidentes em política externa.

É preciso não perder de vista que é sempre o presidente quem conduz a política externa, mas geralmente ele o faz seguindo objetivos produzidos pelo corpo burocrático. $O$ interesse desse trabalho são as situações em que 0 presidente extrapola esses limites. Como define Danese, sempre que o presidente agir de modo independente dessa ação protocolar de política externa, ele estará fazendo diplomacia presidencial. Para praticamente todos os autores analisados, assim como para este trabalho, a diplomacia presidencial é caracterizada como oposta a essa diplomacia protocolar, tradicional, também chamada burocrática-profissional ${ }^{1}$.

Cabe notar também que $\mathrm{o}$ interesse deste trabalho reside em analisar a atuação de um ator específico na condução e formulação da política externa brasileira, a Presidência da República. Não é seu objeto de estudo como ocorre uma decisão (formulação) ou o que acontece após a tomada das decisões (implementação). Também não serão abordadas as idéias que influenciaram as decisões ou as preferências e interesses que podem ter contribuído para uma decisão. Além disso, não será analisada aqui nenhuma gestão presidencial específica. Essa análise se centra no aspecto conceitual e não no aspecto de

\footnotetext{
${ }^{1}$ Conferir tabela na p. 53 dessa dissertação.
} 
prática político-diplomática. Essa pesquisa pretende trazer um pouco mais de luz a esse conceito, já que ele é de grande importância para compreender a ação dos chefes de Executivo nacionais no cenário externo.

Já que se trata de uma análise conceitual é uma pesquisa essencialmente teórica e a metodologia utilizada foi uma análise de publicações ${ }^{2}$ referentes ao tema. Não foi necessário uma seleção minuciosa do material, pois há poucas publicações que usam esse conceito de forma rigorosa. Assim, serão analisados os livros e os artigos científicos que utilizam o conceito.

Essa pesquisa tratou essencialmente do aspecto de formulação da política externa, portanto cabe aqui primeiramente se fazer uma distinção do seu significado:

“... concepção de uma conduta que se expresse em atos ou palavras, com relação a um tema de natureza internacional, por iniciativa ou reação, por parte de atores privilegiados na arena decisória e que esta se traduza, em última análise, como a posição do governo em questão." (Pinheiro, 2000:453)

Que não dever ser confundida com implementação:

“... mera aplicação de uma decisão, desde que neste processo não se acrescente ou se altere substancialmente o conteúdo da mesma caso em que se deve retornar à categoria de formulação." (Pinheiro, 2000:453)

Já por decisor, segundo a clássica definição de Snyder e parceiros ${ }^{3}$, se entende:

“... única e exclusivamente, os chamados funcionários de governo. Nenhum cidadão privado, não importa quão poderoso, deverá ser tratado como decisor, a menos que este esteja, na ocasião, à frente de uma agência federal. Neste sentido, exclui-se desta categoria o papel porventura desempenhado por partidos políticos, grupos de interesse e/ou quaisquer agências não governamentais". (apud Pinheiro, 2000:453)

Cabe aqui outra importante distinção, que também sofre de confusões:

\footnotetext{
${ }^{2}$ As traduções de textos em língua estrangeira que constam nessa dissertação foram todas realizadas pela autora.

${ }^{3}$ Snyder, R. C.; Bruck H. W. \& Sapin, B. "Decision Making as an approach to the study of internacional politics”. Foreign Policy Analysis Project Series, New Jersey: Princeton, n.3, 1954.
} 
Quando se fala de Relações internacionais o sentido é amplo, ela abarca as relações entre diversos atores internacionais. Desse modo:

"... junto com os estados, possuem também papel importante nas relações internacionais organismos de índole internacional (ONU, NATO e outros sistemas de aliança internacional, COMECON, OPEC, etc.), organismos integrativos como as comunidades européias, grupos de pressão como as empresas multinacionais e as internacionais partidárias e sindicatos, organismos como a OLP e por aí afora." (Pistone, 2004:1089)

Em relação ao conteúdo, as Relações Internacionais podem ter ênfase nos aspectos político, econômico, social, cultural, etc., de caráter cooperativo ou conflituoso. Também se pode falar de Relações Internacionais de um país, o que se refere à posição desse país no cenário internacional, seja no âmbito regional ou mundial.

Já quando se fala em relações exteriores, essas se referem às relações de um estado específico com outros estados, por exemplo, as relações BrasilArgentina. A política externa seria então a essência das relações exteriores.

É importante fazer-se alguns esclarecimentos sobre o que se considerou neste trabalho diplomacia e política externa, categorias chaves para o entendimento do conceito de diplomacia presidencial.

Morgenthau (2003:967) descreve a diplomacia da seguinte forma:

"... é necessário criar as condições sob as quais deixará de ser impossível estabelecer um Estado mundial (...) A esse método de criar pre-condições para uma paz permanente chamamos de paz por meio de acomodações. E o seu instrumento é a diplomacia".

Já para Wight (2002:107):

"A diplomacia é o sistema e a arte da comunicação entre os estados. O sistema diplomático é a instituição mestra das relações internacionais. Ele pode ser convenientemente dividido em duas categorias: as embaixadas residentes e as conferências".

Segundo Ostellino (2004:348-9), apoiando-se na definição de Oxford English Dictionary, a diplomacia é "a condução das relações internacionais através de negociações. O método através do qual estas relações são 
reguladas e mantidas por embaixadores e encarregados; o ofício ou a arte do diplomata", ele esclarece que "o objeto da diplomacia é, portanto, o método através do qual são conduzidas as negociações e não o conteúdo das negociações".

Vê-se então que, de um modo geral, diplomacia é a condução oficial das relações internacionais entre Estados por meio de pessoas credenciadas, os diplomatas. Esse conceito também está associado ao órgão responsável pela execução da política externa. Assim, no Brasil diplomacia aparece geralmente nos trabalhos acadêmicos como sinônimo do Itamaraty. Esta pesquisa identificou a diplomacia com a primeira definição. Quando aqui se fala no órgão responsável pela diplomacia, se utilizou preferencialmente Ministério das Relações Exteriores (MRE) ou Itamaraty, ao invés de diplomacia.

Mas a diplomacia não deve ser interpretada como sinônimo de política externa. Ela é apenas um instrumento pelo qual os Estados executam sua política exterior; cabe aqui também uma definição desta última:

"Por política externa deve-se entender o estudo da forma como um Estado conduz suas relações com outros Estados, se projeta para o exterior, isto é, refere-se à formulação, implementação e avaliação das opções externas, desde o interior de um Estado, vistas desde a perspectiva do Estado, sem atender à sociedade internacional como tal." (Arenal, 2002:22)

Altemani (2005:2) citou esta definição de política externa de Arenal (2002), discordando dele na última frase, pois considerou a política externa como uma das áreas das relações internacionais, porém com maior ênfase no papel do Estado.

Já para Letícia Pinheiro (2004:7):

"A política externa pode ser definida como o conjunto de ações e decisões de um determinado ator, geralmente mas não necessariamente o Estado, em relação a outros Estados ou atores externos - tais como organizações internacionais, corporações multinacionais ou atores transnacionais -, formulada a partir de oportunidades e demandas de natureza doméstica e/ou internacional." 
Neste trabalho interpreta-se política externa segundo a definição de Arenal, mantendo a ressalva de Altemani. Aliás, essa posição coincide com a definição de Pinheiro, discordando-se dela apenas no que se refere à possibilidade de ênfase em atores que não sejam necessariamente o Estado.

A seguir faz-se uma descrição breve dos capítulos.

No capítulo 1 tentou-se traçar o contexto político-institucional que permitiu o surgimento da diplomacia presidencial no Brasil. Para tal, foram analisados dois atores apontados pela literatura como os mais relevantes em matéria de política externa: o presidente da República e o Itamaraty. Nessa análise também se abordou algumas "crenças" sobre a política externa brasileira. Isto é, idéias já cristalizadas na literatura e que são importantes para a compreensão da política externa no Brasil. Buscar-se-á traçar o novo comportamento do presidente da República nesse âmbito.

No capítulo 2 foram analisadas as publicações que abordaram a temática e que definiram o conceito de diplomacia presidencial. Isso contribui para a compreensão do estatuto teórico desse conceito.

No capítulo 3 o objetivo foi analisar a produção internacional que busca dar conta da ação do presidente da República em assuntos externos. Esses estudos serão confrontados no capítulo seguinte com o conceito de diplomacia presidencial, para então apreender o que o mesmo trouxe de novo ao debate já existente.

Por fim, no capítulo 4 têm-se as considerações finais onde serão levantadas hipóteses, mais do que conclusões. 


\section{Capítulo 1 - Principais atores na arena de política externa BRASILEIRA}

Antes de se estudar o papel do presidente em política externa no regime presidencialista brasileiro, é preciso esclarecer em qual contexto o presidente toma as suas decisões de política externa.

Primeiramente, suas funções derivam do regime de governo do país. Esse regime é o presidencialista. Será apresentada uma definição de presidencialismo, porém no Brasil esse regime tem especificidades, que também serão descritas no item 1.1.1.

A seguir serão descritas as atribuições constitucionais e as características do presidente da República e também do MRE, considerados aqui os atores principais na política externa brasileira. Por esse motivo, parte-se do pressuposto que não se pode explicar o novo comportamento do presidente em política externa - a diplomacia presidencial - sem compreender-se 0 comportamento do Itamaraty.

Antes de descrever o Itamaraty, serão expostas algumas características da política externa brasileira, visto que essas têm relação direta com 0 comportamento do MRE. Isso ainda dentro do intuito de fornecer uma visão do contexto de atuação do presidente da República. O presidente toma suas decisões segundo as regras do regime presidencialista e também influenciadas pelas "regras de conduta" da nossa política externa. Essas últimas se referem a um diagnóstico já cristalizado na literatura sobre a política externa brasileira, que, de tão recorrentes, não podem ser deixadas de se mencionar aqui, pois são importantes para a compreensão da política externa no Brasil.

\subsection{O PRESIDENCIALISMO}

Segundo Linz (1991:65), no sistema presidencialista "o povo elege diretamente o Executivo, por um período determinado. A Constituição outorga consideráveis 
poderes a esse Executivo, que decide por si só a composição de seus ministérios e exerce controle total sobre a administração".

Linz enumerou duas características institucionais de destaque no sistema presidencialista: primeira, "o presidente reclama total legitimidade democrática", ou seja, o autor coloca a questão se este tem mais legitimidade democrática para falar em nome do povo ou o Congresso, também eleito em voto popular. A segunda é o fato dos presidentes serem eleitos por um período de tempo determinado, que não pode ser modificado em condições normais, isto é, o mandato não pode nem ser encurtado (salvo a possibilidade de impeachment) e nem prorrogado (salvo em países com reeleição). Aqui está exposta a idéia de mandato, que se constitui no período de exercício legítimo de um cargo eleitoral ${ }^{4}$. No Brasil o mandato de um presidente corresponde a 4 anos, que é o tempo em que ele foi autorizado pelo povo, via eleições, a ser seu representante, sendo que ele pode ser reeleito.

Assim, numa conceituação simplificada, presidencialismo é um sistema de governo no qual o presidente - eleito pelo povo e que permanece no cargo por tempo determinado pela Constituição - detém o poder de chefe de estado (chefe simbólico, que representa a nação) e de chefe de governo, ao mesmo tempo.

Embora o presidencialismo suponha a separação do poder, na maioria dos atuais sistemas presidenciais observa-se um movimento no sentido da concentração de autoridade nas mãos do Executivo. Na verdade, a influência dos executivos sobre a política externa varia em função do desenho institucional, ou seja, dependerá do sistema de governo, parlamentarismo ou presidencialismo e se a constituição procura o equilíbrio entre os três poderes ou se ela tende à concentração de poder num deles (Malamud, 2003).

A maior parte dos países da América Latina se encaixa no segundo caso. $O$ regime desses países tem sido caracterizado por uma propensão à

\footnotetext{
${ }^{4}$ Conferir verbete "mandato", In: Houaiss, 2004.
} 
acumulação de poder no Executivo (Malamud, s.d). Por outro lado, como ressalva Sadek ${ }^{5}$, na América Latina tem se desenvolvido vários mecanismos visando cercear o poder do Executivo, como o impedimento constitucional de reeleição (refletindo o medo das ditaduras), o impeachment, a criação de agências independentes, dentre outros.

No Brasil, a reforma da Constituição de 1988 aumentou o grau de autonomia do presidente, reconhecendo a autoridade de promulgar leis em caso de urgência - são as medidas provisórias -, deter prerrogativas exclusivas quanto à determinação do orçamento e da legislação fiscal e a permissão para exigir procedimentos de urgência na apresentação e votação de leis.

\subsubsection{Especificidades do presidencialismo brasileiro}

Segundo Abranches (1988:19), o modelo de democracia brasileira tem especificidades em comparação às outras democracias: o seu presidencialismo, que ele classificou como presidencialismo de coalizão.

Para conceituar essa característica do presidencialismo brasileiro, Abranches chama a atenção para o fato de que a maioria dos regimes liberaisdemocráticos do pós-guerra é parlamentarista. Os EUA são a única democracia puramente presidencialista. Entre as democracias liberaisdemocráticas estáveis, não há nenhuma com uma combinação de representação proporcional, multipartidarismo e presidencialismo, além do Brasil. $^{6}$

Países com grande proporção de coalizões, que são heterogêneas internamente, são sociedades com maior pluralidade e diferenciações sociais (1988:20). Isso porque nas sociedades mais divididas a governabilidade e a

\footnotetext{
${ }^{5}$ Conferir Boito Jr., 1993. Neste livro há um debate de vários intelectuais - dentre eles Maria Teresa Sadek (p.27 a 36) - sobre presidencialismo e parlamentarismo.

${ }^{6} \mathrm{O}$ autor discorre (1988:19) brevemente sobre as características de cada país liberal-democrático do pós guerra para provar seu argumento.
} 
estabilidade institucional requerem uma formação de alianças e uma maior capacidade de negociação.

Assim, o autor define o "presidencialismo de coalizão":

"Apenas uma característica, associada à experiência brasileira, ressalta como uma singularidade: o Brasil é o único país que, além de combinar a proporcionalidade, o multipartidarismo e o 'presidencialismo imperial' ${ }^{7}$, organiza o Executivo com base em grandes coalizões. A esse traço peculiar da institucionalidade concreta brasileira chamarei, à falta de melhor nome, 'presidencialismo de coalizão' (1988:21-22)."

Para esse autor as coalizões se formam segundo dois eixos: o partidário e o regional (estadual). Assim, a Presidência tem que garantir, via coalizões, a base de sustentação do governo, tanto em relação aos partidos quanto em relação aos estados. O governo precisa ter garantias de que possa bloquear ou promover mudanças constitucionais, segundo seu interesse. ${ }^{8}$.

Quanto ao eixo partidário, os ministérios são controlados pelos partidos que participam das coalizões. Segundo o autor, no período de 1946 a 1964 o número de partidos no governo foi maior que a média de partidos parlamentares efetivos. Essa capacidade de controle ministerial nem sempre corresponde ao peso do partido no Congresso, principalmente em relação aos partidos menores. Isso significa que o partido tem um peso parlamentar e um peso governamental.

Quanto ao eixo regional, a participação dos estados nos ministérios tem uma predominância do triângulo Rio de Janeiro-São Paulo-Minas Gerais. Mas alguns estados são representativos de suas regiões, como por exemplo Bahia, Pernambuco e Ceará o são para o Nordeste.

\footnotetext{
${ }^{7}$ Presidencialismo imperial se refere ao que acontece quando o balanço constitucional entre o poder presidencial e a accountability presidencial está desequilibrado em favor do primeiro. Em política externa especificamente, a disposição tem sido de passar o poder e a responsabilidade para o presidente, mas o abuso de poder pode ser contido pela separação de poderes, prevista na constituição (Schlesinger, Jr., 1988:127).

${ }^{8}$ Cabe notar aqui que o autor explica (p.22 a 24) a formação de coalizões no Brasil em relação ao período de 1946 a 1964.
} 


\subsubsection{Atribuições constitucionais e características do presidente}

Esse item descreve primeiramente as funções do presidente da República de modo geral, para, em seguida, analisar as especificidades da política externa.

No sistema de governo presidencialista brasileiro, as funções do presidente da República são numerosas e definidas na constituição federal. Para executá-las, o presidente trabalha com auxiliares diretos, os ministros de estado, que ele nomeia e destitui livremente, além dos assessores, corpos consultivos, etc.

O capítulo II da Constituição brasileira de 1988 (Título IV: das organizações dos poderes) versa sobre o poder Executivo e dita quais são essas atribuições do presidente da República. Além das funções executivas, o presidente exerce também um poder legislativo, como o veto a leis aprovadas pelo Congresso Nacional e a elaboração de medidas provisórias.

Em relação aos princípios orientadores da nossa política externa eles são ditados pela Constituição brasileira de 1988 e correspondem a: independência nacional, prevalência dos direitos humanos, autodeterminação dos povos, nãointervenção, igualdade entre os Estados, defesa da paz, solução pacífica dos conflitos, repúdio ao terrorismo e racismo e cooperação entre os povos para o progresso da humanidade (título I, dos princípios fundamentais, art.4ํㅜㄹ incisos I a X). Assim, a priori a política externa não pode contradizer nenhum desses princípios. Isto também coloca um grau de limitação às ações do seu formulador.

Os incisos VII, VIII, XIV, XIX e XX do artigo 84 da Constituição brasileira de $1988^{9}$ explicitam as funções do presidente especificamente em relação à política externa. Em linhas gerais elas são: manter relações com estados estrangeiros, celebrar tratados e convenções e atos internacionais, nomear embaixadores, declarar guerra (com aprovação do Congresso) e celebrar a paz. Pode-se assim observar que o presidente da República é,

\footnotetext{
${ }^{9}$ Conferir cap. II, seção II, art.84º da Constituição Brasileira de 1988.
} 
constitucionalmente, o detentor da responsabilidade em relação à política externa do país.

Porém, isso não significa que o presidente possa exercer essas atribuições em política externa de modo isolado. Em alguns casos ele necessita do aval do poder Legislativo. Além disso, o poder Legislativo tem a função de fiscalizar a administração do Executivo, não apenas na política externa, mas inclusive nesta. O Congresso também cumpre o papel de fazer posterior ratificação das ações e compromissos assumidos pelo Executivo externamente.

Portanto, a responsabilidade da política externa brasileira cabe ao presidente da República. E nessa função ele é assessorado pelo Ministério das Relações Exteriores (MRE), o Itamaraty.

Além do MRE, outros órgãos auxiliam o presidente em assunto de política externa. Danese (1999) nota que a assessoria direta do presidente no Brasil é composta por uma estrutura instável, pois muitos órgãos mudam de função (e nome) conforme a mudança de governo. No governo Fernando Henrique Cardoso por exemplo, essa assessoria presidencial estava dividida entre a Assessoria Especial, o chefe da Casa Militar, o Secretário de Assuntos Estratégicos e órgãos colegiados como a Câmara de Comércio Exterior e a Câmara de Relações Exteriores e Defesa Nacional.

É importante esclarecer que o presente trabalho não se deterá no estudo desses órgãos, pois o foco é a atuação presidencial, porém será destacado no próximo item o papel do MRE, já que o chanceler, juntamente com o presidente da República, são os principais atores da política externa. Nessa pesquisa 0 foco foi um ator específico do Executivo, o presidente da República, que é constitucionalmente o chefe desse poder.

\subsection{ALGUNS ASPECTOS DA POLÍTICA EXTERNA BRASILEIRA}

- Política externa como política de estado

Segundo Fernandes (2004: s.p.), a política externa tem duas dimensões de 
planejamento: a política de estado e a política de governo. Como política de estado ela reflete os interesses mais consolidados do Estado Brasileiro.

Para o autor, nesse aspecto, existem diretrizes de continuidade da política externa brasileira, materializadas no Itamaraty, que sempre fortaleceu a independência da política externa brasileira, segundo os interesses de proteção da nossa margem de autonomia no mundo. Os princípios de tal política de estado estão na própria Constituição ${ }^{10}$. $\mathrm{O}$ autor ressalta que em consonância com essa política a diplomacia brasileira tem sido defensora da manifestação da ordem mundial através das instituições multilaterais de alcance universal. Apesar da forma de execução desses objetivos variarem de um governo a outro, esses princípios constituem a "espinha dorsal de nossa agenda exterior". Eles projetam uma visão de mundo que delimita a própria atuação do governo (Fernandes, 2004: s.p.).

Diferentemente, como política de governo, a política externa expressa as prioridades, o estilo, a ênfase e o tom defendidos pelas forças responsáveis pela direção do Poder Executivo nacional, e que variam segundo o governo.

Para Lima (1996:5) a mudança de regime militar para o civil mudou o contexto decisório, com um alargamento do espectro de atores, instituições e interesses, todos "com voz e voto" no processo de decisão sobre política externa. Começase uma nova relação entre política externa e política doméstica. Essa nova relação desfez a confusão entre política externa de estado e de governo, que é conseqüência do papel historicamente preponderante do Itamaraty na formação da política externa brasileira do regime militar, segundo a autora.

Lima faz um destaque sobre isso em relação ao governo Cardoso, que nos interessa aqui, pois lembremos que foi com ele que a diplomacia presidencial teve destaque no país: "De todos os governos civis desde o fim do ciclo militar, é o de Fernando Henrique Cardoso aquele em que mais claramente se

\footnotetext{
${ }^{10}$ Conferir p. 17 dessa dissertação.
} 
diferencia o componente governamental do componente estadista da política externa" (1996:6).

O componente estadista da política externa é representado pelo conceito de interesse nacional, ou seja, é devido ao "interesse nacional" que a política externa está acima da política doméstica e dos partidos. E Lima (1996:6) complementa com a idéia de diplomacia pública: "Foi no atual governo que se passou a utilizar a expressão 'diplomacia pública', em uma clara alusão a que agentes do Estado têm um mandato da sociedade para defender e representar os 'interesses nacionais'...".

- Política externa como uma política específica

As decisões de política externa, apesar de terem semelhança com as de política doméstica, têm características que lhe são próprias: o governo ao tomar uma decisão de política doméstica tem um aparato que lhe protege (meios administrativos, policiais e judiciais a sua disposição). Ele "detém o controle da vida interna do país". Ao contrário, quando toma uma decisão de política externa, ele não controla as possíveis reações dos países estrangeiros porque não detém 0 controle sobre as decisões desses países (Duroselle, 1967:436).

Assim, a política externa tem, sim, suas especificidades - como a exigência do conhecimento específico e a questão do segredo governamental que envolve as atividades ligadas à segurança do país. Mas do mesmo modo que qualquer política o tem, e é isto que diferencia uma política pública da outra.

Há uma abordagem - a realista - que considera a política externa como uma política independente das outras políticas públicas. O argumento realista considera o Estado como ator unitário e pressupõe não haver no interior desse Estado conflito de interesses ou divisão interna com relação à política externa. Assim, a política externa é coerente com este Estado, com o interesse nacional. Segundo Lima (2000), quase todos os realistas adotam a premissa do ator unitário, que postula a especificidade da política externa e elimina da análise a influência - seja de causalidade ou de condicionamento - dos fatores 
domésticos sobre a política externa.

No Pós-guerra Fria o argumento realista se enfraquece, pois aumenta a visibilidade dos efeitos da política interna sobre a política externa. Novos atores e temáticas foram incorporados, problematizando a concepção do Estado como ator unitário.

Se há uma separação da política doméstica em relação à política externa, implica-se um processo decisório diferenciado para ambas políticas. Os realistas argumentam com isso que a Política pára na fronteira da nação (Lima, 2000: 273-4). Ou seja, a política externa se encontra fora da esfera política e dentro da esfera tecnoburocrática, no Brasil representada pelo Itamaraty. Isto significa a despolitização do processo decisório de política externa.

Pode-se concluir que "se as diferenças entre política externa e doméstica deixam de existir, também não mais se sustenta à alegação de um processo decisório distinto para as questões internas e externas" (Lima, 2000:277) e assim, não cabe o argumento de que a política externa é uma política específica e de Estado e pode-se sustentar que ela é uma política pública e portanto uma política de governo.

- Continuidade e consenso na política externa brasileira

Sobre a crença na continuidade e no consenso a respeito das orientações gerais da política externa brasileira, Lima (1996:27) admite somente o fato de que essa política externa tem um maior grau de continuidade e consenso quando comparada a outros países da região.

O MRE formula conteúdos específicos de sua "política setorial" e tem uma capacidade de obter respaldo político interno para eles. Isso é o que garante uma certa permanência no tempo dos paradigmas orientadores de política externa ${ }^{11}$.

\footnotetext{
${ }^{11}$ O Itamaraty formulou também paradigmas alternativos de política externa, consideradas teorias de ação diplomática. O MRE ao longo da história republicana articulou dois paradigmas de política externa: aliança especial com os EUA e o paradigma globalista (Lima, 1994:34-5).
} 
- Baixo interesse dos políticos e da população por temas de política externa

O interesse por política externa por parte dos políticos em geral, tanto em relação a sua atuação dentro dos próprios partidos políticos, quanto no Congresso Nacional, é tido como baixo. Para os políticos brasileiros o MRE está isolado da política doméstica, além de ser desprovido de "vagas" para dividir com sua "clientela" (Arbilla 2000: 344).

O interesse da população por política externa também é considerado baixo porque a política externa não tem um caráter imediato. Como conseqüência, a opinião pública acaba se desinteressando, já que isso não a afeta diretamente, exceto em questões de economia e finanças. Nessas questões a população pode sentir os efeitos na política doméstica de seu país.

Além disso, a minoria interessada e influente, tende a ver a diplomacia de seu país pelo prisma de seus interesses setoriais (Danese,1999:96). Apesar de hoje haver mais atores envolvidos no processo de formulação da política externa brasileira, eles têm interesses em temas muito específicos de política externa. Para Arbilla (1997:109), é por isso que o Itamaraty permanece o representante geral do país perante a comunidade internacional.

Considera-se adequada nesse trabalho à abordagem que interpreta a política externa como uma política pública e não como uma política específica, isto é, diferente de todas as outras políticas públicas. Desta forma, a abordagem adotada é a da política externa como uma política de governo e não uma política de Estado. Como uma política de governo deve ser levado em conta a conjuntura e também os diversos grupos de interesse existentes em torno de uma questão. 
Sobre o fato da sociedade em geral apresentar baixo interesse por questões que envolvem política externa, isso reflete na diplomacia presidencial, já que a recepção na opinião pública é um de seus eixos ${ }^{12}$. A diplomacia presidencial reage à opinião pública, seja tentando cooptá-la, seja impressioná-la, mas sempre dialogando com ela. Danese ressalta (1999:90) que muitas decisões de política externa são tomadas exclusivamente em função da opinião pública. Porém, a repercussão da diplomacia presidencial fez com que o interesse da população em geral por política externa aumentasse, já que tornou o tema mais visível.

Estabelecendo agora uma relação entre política externa, política pública, opinião pública e diplomacia presidencial, pode-se dizer que com a maior visibilidade da figura presidencial em questões de política externa, ou seja, com a diplomacia presidencial, a política exterior passou a ser de interesse não só da corporação diplomática, mas da sociedade como um todo. Assim, a diplomacia presidencial serviu como um instrumento capaz de dar a política externa o sentido de política pública (Cerqueira, 2005:54-5).

\subsection{ATRIBUIÇÕES CONSTITUCIONAIS E CARACTERÍSTICAS DO ITAMARATY}

O Ministério das Relações Exteriores (MRE), o Itamaraty, é o órgão responsável por assessorar o presidente da República em questões de política externa. Constitucionalmente, cabe a ele implementar a diplomacia brasileira.

A atual estrutura de funcionamento do Ministério das Relações Exteriores decorre do Decreto $n^{\circ} 5.032$, de 05/04/2004 e dita a função do ministro de Estado das relações exteriores, dentre outros cargos. Para desempenhar suas funções - auxiliar o presidente da República na formulação e execução da política externa brasileira, manter relações com governos estrangeiros (dimensão bilateral e regional da diplomacia) e com organismos internacionais (dimensão multilateral) - o MRE se estrutura em departamentos, que, por sua vez, se desdobram em divisões, e inclui outros órgãos de coordenação,

\footnotetext{
${ }^{12}$ Esse aspecto da diplomacia presidencial será abordado no capítulo 2 dessa dissertação, p. 37-8.
} 
assessoria e apoio. Além disso tem-se a Fundação Alexandre de Gusmão (FUNAG), que é uma entidade vinculada - responsável pela pesquisa e cooperação na área de Relações Internacionais e do Instituto Rio Branco, responsável pela seleção e treinamento dos diplomatas.

O MRE é constituído pela Secretaria de Estado, que opera no Brasil, e pelas Repartições no Exterior, que compreendem as Missões Diplomáticas, as Missões e Delegações junto a Organismos Internacionais, e as Repartições Consulares.

Para Seitenfus (1994:32) a concepção da política externa brasileira é, em geral, concentrada nas mãos do ministro das relações exteriores, mesmo que formalmente a responsabilidade seja do presidente. Para esse autor, 0 ministro, caso tenha uma personalidade forte, conhecimento e apoio político, pode-se tornar o idealizador da política externa brasileira. Isso é mais real quanto menos o presidente tiver interesse em assuntos externos.

Uma das tarefas do ministro de política externa é apresentar a política externa do país para várias platéias, internas e externas. Internamente, para o parlamento, jornalistas, empresários, professores universitários, com o objetivo de tornar clara as opções de política externa e fazer com que estas "ganhem raízes na sociedade" (Amorim,1997:15). Externamente, os objetivos são evidenciar o perfil do país para a comunidade internacional, que são os Estados, as organizações multinacionais e as ONGs (Organizações Não Governamentais). Para Amorim, esses dois planos, o interno e o externo, não estão dissociados. O que sustenta o projeto diplomático nacionalmente é o que dá credibilidade ao país externamente.

Mas sendo esta uma pesquisa na área de Política, o que interessa aqui são as características do MRE que extrapolem o constitucional e que permitem compreender a política externa em seu viés político. Elas serão descritas a seguir.

- Esprit de corps ou identidade organizacional de seus membros 
Segundo Barros (1986: 30-1), os diplomatas cultivam um senso de isolamento em relação aos outros órgãos governamentais, tanto devido à sua grande mobilidade geográfica, que é própria do cargo, como devido ao forte sprit de corps entre os diplomatas, que vêem a si próprios como diferentes dos outros burocratas.

Essa forte identidade organizacional, essa coesão interna, é fundamentada na própria história da instituição. Seus padrões de carreira, seu controle sobre o recrutamento e sistema de treinamento e de avaliação de seus membros (Mello, 2000; Holzhacker, 2005:56), cria uma forte identidade e valorização profissional de seus membros.

Devido a essas características o MRE se diferencia das outras agências de estado (Lima,1994; Mello, 2000; Fernandes, 2004).

- Eficácia e profissionalismo

Se internamente o MRE sustenta a imagem de um ministério isolado; externamente "o profissionalismo e a competência legitimaram a atuação do Itamaraty (Barros,1986:31)". Esse profissionalismo torna-se a marca do MRE, tanto no Brasil, quanto no exterior. Para Fernandes (2004:s.p.), o Itamaraty é tido como "um dos corpos diplomáticos mais profissionais e melhor preparados do mundo... Juntamente com as Forças Armadas é uma das instituições permanentes mais consolidadas do Estado Brasileiro".

Esse profissionalismo e eficácia do Itamaraty se transformaram em mais uma das "crenças" a respeito da política externa brasileira (Cheibub,1985:130; Barros,1986:29), por isso cabe aqui ser destacada.

- Insulamento

As possíveis causas do insulamento do MRE segundo Barros (1986:31) são:

"A origem social, a competência do treinamento, 0 isolamento e 0 relativo esoterismo dos diplomatas, tudo isso associado ao fato de constituírem eles um grupo homogêneo de elite, contribuiu para insular o processo de formulação da política externa (e em especial sua implementação) - atitude tomada por muitos, mas não por todos." 
Para Lima (1994) esse insulamento está relacionado a um isolamento do MRE em relação a influências vindas do seu ambiente político e social. Isso é conseqüência da institucionalização do serviço diplomático e da sua missão organizacional, que não gera vínculos específicos ou clientelas particulares na sociedade e na política interna. Para a autora, o insulamento tem seu lado positivo e negativo. O lado positivo é que ele torna o MRE menos permeável a ingerências políticas do contexto da administração brasileira, caracterizada pela escassa institucionalização. O lado negativo é que o insulamento fragiliza o MRE, que fica com uma menor inserção no ambiente interno, tornando o seu poder mais dependente da autorização do Poder Executivo.

- Autonomia

Segundo Cheibub (1985:113-4), o MRE tem se fortalecido ao longo da história da formação do Estado nacional brasileiro. Com isso, os diplomatas adquiriram uma autonomia perante os outros setores sociais e até perante o próprio Estado. Essa situação confere uma margem de iniciativa crescente na formulação e implementação da política externa.

Segundo Lima (1994:33), mantendo os demais elementos constantes, a autonomia relativa do Itamaraty é maior em períodos de autoritarismo do que nos democráticos, porque nesses últimos as decisões de política externa devem ser ratificadas pelo Congresso. "Mas, dadas as características imperiais do presidencialismo brasileiro e as próprias da corporação diplomática ausência de clientelas específicas na sociedade ou em política - o poder da última é função da sinergia estabelecida entre ela e o poder Executivo". Essa sinergia nem sempre se observa.

\section{- Flexibilização}

No fim dos anos 60 e início dos 70, vários órgãos burocráticos começaram a competir com o Itamaraty em matéria de comércio exterior. O desdobramento dessa competição resultou na modernização do MRE e na sua adaptação às operações comercias. Se antigamente o Itamaraty podia manter uma posição praticamente hegemônica, agora ele passa a lidar com o fato de que existem 
outros atores mobilizados para participar da política externa brasileira. Assim, o controle das relações exteriores tornou-se mais complicado, podendo envolver não só o MRE, mas também outros ministérios, o Banco Central, multinacionais, ONGs, etc.

Historicamente, o Itamaraty sofreu uma crise de identidade desde os anos 70 ao enfrentar duas ameaças: ampliar a capacidade de controle e coordenação de outros atores envolvidos na arena externa, e desenvolver uma capacidade de lidar mais efetivamente com assuntos comerciais (condição sine qua non para a primeira; Barros,1986: 38).

Sobre isso Barros (1986:39) concluiu que atualmente uma das ameaças que o Itamaraty está enfrentando é justamente ter que:

"tentar integrar tanta gente quanto possível no processo de realização e implementação da política externa, sem perder o controle e sem dar margem à deterioração do padrão de qualidade do serviço diplomático."

Ainda sobre o controle da política externa pelo MRE, perante esse quadro de múltiplos atores tentando agir de modo independente (do Itamaraty) em matéria de política externa, Altemani (2005:38) complementou Barros:

"Em certo sentido, o Itamaraty está tentando controlar todos esses atores relativamente independentes, para evitar incoerência e dissonâncias por parte dos atores para-governamentais, que poderiam criar embaraços ou problemas para a implementação da política externa do país."

Lafer (2002:16) acrescenta que, num regime democrático, e na era da globalização, a política externa não se reduz às chancelarias:

"Ela requer lidar tanto com a multiplicidade de atores governamentais e não-governamentais - presentes na vida internacional, quanto com a agenda de opinião pública."

Holzhacker (2005: 56-7) expõe a nova dinâmica das relações sociedade civil e diplomacia:

"É consensual na literatura que a abertura democrática, a partir da segunda metade dos anos 80 , trouxe uma nova dinâmica na relação estado-sociedade nos aspectos relacionados à política externa brasileira." 
Essa nova dinâmica se refere à criação de canais de diálogo, consulta e participação abertos à sociedade civil em temas de decisão específicos de política externa. A política externa brasileira se torna mais permeável à sociedade civil brasileira, a diferentes interesses. Isso poderia levar a um risco de fragmentação do processo de decisão de política externa. Mas esse risco não se realizou nos anos 90 , pois "o processo foi conduzido e orientado pela própria diplomacia brasileira, que permaneceu sendo o principal canal de informação, decisivo no processo de formação da opinião da elite e da massa (2005:57)".

Segundo Holzhacker (2005:59) a análise da relação sociedade-Itamaraty, até os anos 90, partia de duas premissas: a) a diplomacia brasileira sempre foi marcada por alta coesão e autonomia; b) a sociedade (elite e massa) mostrou um baixo interesse em política externa e conseqüentemente baixa mobilização e participação. Isso, acrescido do pouco conhecimento da sociedade em política externa é o que legitima a ação do Itamaraty.

A partir da metade dos anos 80 ocorreram mudanças - nacionais e internacionais - que modificaram essas duas premissas. O cenário internacional era do pós guerra-fria, com novos atores e temas; isso trouxe novos desafios à inserção internacional dos países. Somado a isso se tem o processo de democratização, citado acima. A sociedade reagiu a essas mudanças organizando-se e mobilizando-se. O MRE combinou um esforço de ampliar os espaços de participação social com um discurso de reafirmação do seu papel institucional, mantendo o controle da agenda, da formulação e implementação da política externa.

Os temas da agenda externa integraram diretamente a agenda doméstica e como conseqüência houve uma maior mobilização dos interesses da sociedade, tornando a atuação do Itamaraty mais complexa (2005:61). A necessidade de aproximação com outros atores da sociedade - setores econômicos, imprensa, ONGs, com os próprios parlamentares, ou seja, com a 
opinião pública em geral - pode ser observada nos documentos e discursos diplomáticos do MRE (2005:61-2). ${ }^{13}$

Especificamente em temas comerciais é que o processo de consulta e diálogo com a sociedade se tornou mais institucionalizado. Nesses temas o diálogo MRE-sociedade configura-se em um canal permanente e aberto de consulta.

A literatura é consensual no fato que o Itamaraty se tornou mais aberto à sociedade, mas com críticas de que ainda faltam mecanismos institucionais e permanentes de diálogo (2005:92). Percebe-se padrões dessa abertura, que variam do maior ao menor grau de institucionalização, dependendo do tema e interesse da diplomacia brasileira.

Esse capítulo analisou os dois atores considerados aqui como os principais em matéria de política externa: o presidente da República e o Itamaraty.

Primeiramente foram abordadas as funções constitucionais do presidente da República. Isso foi feito analisando-se o regime de governo do país, que é o presidencialista, tendo em vista que as características do presidente derivam de tal regime. Porém, o presidencialismo no Brasil tem suas especificidades, por isso foi chamado de "presidencialismo de coalizão". No Brasil tem-se um sistema fortemente presidencialista, o que foi um dos fatores que contribuíram para o presidente agir de modo autônomo em política externa.

A seguir foram analisadas algumas "crenças" sobre a política externa brasileira, que se referem a idéias já cristalizadas na literatura e que são importantes para a compreensão da política externa no Brasil e, concomitantemente, do novo comportamento do presidente da República nesse âmbito.

13 “Os discursos dos principais chanceleres dos últimos 15 anos admitem que um dos efeitos da democracia foi a crescente abertura do Itamaraty às demandas sociais e à participação dos diferentes atores (2005:92)". A autora fornece alguns exemplos desses discursos. 
$\mathrm{Na}$ seqüência foi visto o outro ator, o MRE, e as suas características mais arraigadas na literatura, as "crenças" sobre esse órgão. Foram elas 0 corporativismo, a eficácia e profissionalismo e o insulamento. A seguir viu-se a autonomia e a flexibilização do MRE. O que mais interessa nesse quadro da diplomacia é a flexibilização que o MRE vem passando desde a década de 80 e que consiste em um importante elemento do contexto da diplomacia presidencial.

Através da descrição das características de cada um desses dois atores e do contexto no qual o presidente e o MRE tomam as suas decisões de política externa, traçou-se um quadro, foi nesse contexto que a diplomacia presidencial surgiu no Brasil. Conclusões ou hipóteses sobre isso serão abordadas no capítulo 4 desse trabalho.

No capítulo seguinte serão analisadas as publicações que abordaram a diplomacia presidencial e quais definiram o conceito. Isso contribui para a compreensão do estatuto teórico da diplomacia presidencial. 


\section{CAPÍtUlo 2 - ANÁlise do Conceito de Diplomacia Presidencial}

Nesse capítulo serão analisadas as publicações que trataram do tema diplomacia presidencial, iniciando com uma descrição das mais densas e finalizando com uma análise comparativa entre elas.

Antes porém, será apresentada uma introdução ao tema, dissertando sobre o surgimento da prática de diplomacia presidencial no mundo e no Brasil e em seguida sobre a origem do conceito de diplomacia presidencial na literatura.

\subsection{A ORIGEM}

A diplomacia de chefes de estado e de governo - a chamada diplomacia de cúpula, com condução pessoal de assuntos de política externa - tornou-se freqüente no mundo todo após a consolidação dos Estados-nação soberanos, sendo um forte elemento das monarquias absolutas.

Já a diplomacia presidencial - nome que assume a diplomacia de cúpula em regimes presidencialistas - nasce nos Estados Unidos. O presidente Theodore Roosevelt representa um marco para a diplomacia presidencial americana, que a partir de então se expandiu para outros países. Antes desse presidente ela havia se manifestado de modo esporádico somente, com a Doutrina Monroe e em algumas intervenções dos presidentes Cleveland e Mckinley.

\section{No Brasil}

Nos primeiros quarenta anos de República no Brasil os presidentes não tiveram uma participação ativa na condução da política externa. A única exceção apontada por Danese foi à visita de Campos Sales à Argentina em 1899, a primeira visita oficial de um chefe de estado brasileiro ao exterior. Fora este fato, a decisão de Rodrigues Alves de nomear Rio Branco para ministro das relações exteriores e a de seus sucessores de o manterem no cargo (por quase 10 anos) foi "o maior fato da diplomacia presidencial brasileira, no início da república" (1999:252). Para Danese esse episódio expressa o caráter apagado com que se funda a diplomacia presidencial brasileira. Apesar da 
nomeação de Rio Branco sinalizar a importância que estava se atribuindo à pasta do Exterior - e por isso mesmo escolheu-se alguém com competência para ocupá-la - o autor se pergunta porque não foi o próprio presidente quem assumiu esta responsabilidade para si.

Na literatura brasileira

No Brasil começou-se a falar em diplomacia presidencial a partir do governo Fernado Henrique Cardoso. A partir de 1995 é que se encontram artigos acadêmicos e reportagens jornalísticas utilizando este termo, que desde então se tornou freqüente.

Segundo Danese (1999:29), a diplomacia brasileira incorporou a diplomacia presidencial no seu discurso como um dos elementos da política externa. Esse fato, somado à divulgação na imprensa, contribuíram para a grande projeção do tema. Para o autor, o discurso precedeu a prática, já que a participação ativa de Cardoso na diplomacia não estava presente nem na plataforma eleitoral e nem no discurso de posse do presidente.

A seguir se fará uma análise da literatura sobre o tema, ou seja, as publicações que trabalham com o conceito de diplomacia presidencial, tendo ele como tema central ou não. As publicações que mencionam o termo somente de modo pontual não serão alvo de uma análise mais aprofundada, mas mencionados, seja em nota de rodapé ou seja para se estabelecer alguma comparação no decorrer da análise, com o intuito de cobrir o máximo de publicações que se referiram ao termo e demonstrar a freqüência de seu uso pela literatura.

\subsection{A Literatura}

Serão analisados nesse item o livro de Danese ${ }^{14}$ (1999) e alguns artigos sobre diplomacia presidencial: Guilhon Albuquerque (1996 e 1997), Nuñez (1997),

\footnotetext{
${ }^{14}$ Danese possui também um artigo (2002) que aborda a diplomacia presidencial em um de seus itens. Não será analisado aqui, pois se refere mais ao aspecto da prática do que ao conceitual, além do que não traz inovações em relação ao seu livro, trabalho mais completo.
} 
Malamud (2005), Rojas \& Milet (1999). Há outros autores que publicaram artigos sobre o tema ${ }^{15}$, mas que não serão analisados neste item, pois ou compartilham a mesma visão de Danese, por vezes se referindo a sua definição ou não tocam no seu aspecto conceitual. Por fim serão analisadas a dissertação de mestrado de Cerqueira (2005) e a tese de doutorado de Ayllón (2004), além de um artigo do mesmo autor.

Danese, que é um diplomata de carreira, fez sua tese do Curso de Altos Estudos do Rio Branco e a publicou mais tarde sob a forma de livro ${ }^{16}$. Esse livro é considerado obra de referência para o estudo do tema. É importante frisar também que esse é o único livro publicado no Brasil (e provavelmente no mundo), que aborda o tema como foco central e em seu aspecto conceitual, além do empírico. $O$ autor viveu de perto a realidade da política externa brasileira no que se refere à diplomacia, posto que foi conselheiro político e porta voz do ministro de relações exteriores (Ayllón, s.d.).

Em seu livro, Danese tem o objetivo de definir o conceito de diplomacia presidencial, com suas modalidades de manifestação, sua tipologia e eixos em torno do qual se constrói. É esse aspecto do livro que nos interessa nesse trabalho. Além disso, também fez uma revisão histórica da diplomacia de cúpula no Brasil e no mundo e analisou os aspectos diplomáticos e políticos que envolvem a elaboração e implementação da diplomacia presidencial. Portanto seu trabalho tem um aspecto histórico e outro crítico-analítico.

Danese afirma que diplomacia de cúpula, de chefes de estado e de governo ou diplomacia de mandatários são nomes que descrevem o mesmo fenômeno histórico ou instrumento político-diplomático - ele ressalta que a escolha dessa adjetivação depende do ponto de vista - e que no Brasil, EUA e França assume o nome de diplomacia presidencial. Para ele, quando o presidente tem uma participação pessoal, ativa, efetiva, na concepção e na execução da

\footnotetext{
${ }^{15}$ Conferir edição especial da Carta Internacional (1996), que possui vários artigos que fazem menção à diplomacia presidencial e também Genoíno (1999), Lafer (2000), Carvalho Vieira (2001), Coimbra (2002), Almeida (2004), Roque (2004), Vigevani \& Fernandes de Oliveira (2005), Baptista (2004) e Sales (2006).

${ }^{16}$ Danese, 1999. Sobre esse livro, conferir resenha de Onuki, 2000 e Ayllón, mimeo.
} 
política externa, diz-se que ele pratica a chamada diplomacia presidencial. Essa difere do tipo de diplomacia na qual o presidente conduz a política externa de modo institucional, protocolar, somente desempenhando as funções prescritas na Constituição. Segundo Danese, a diplomacia presidencial pode ser definida como:

"a condução pessoal de assuntos de política externa, fora da mera rotina ou das atribuições ex officio, pelo presidente, ou, no caso de um regime parlamentarista, pelo chefe de estado e/ou pelo chefe de governo." (1999:51)

O autor frisa que a diplomacia de cúpula efetiva é sempre um distanciamento da diplomacia tradicional. Por isso, sugere que para se distinguir o que é ou não diplomacia presidencial é preciso saber o que é a diplomacia tradicional ${ }^{17}$. Assim, quando o presidente excedeu o que corresponderia ao simplesmente protocolar, ele fez diplomacia presidencial, seja em menor ou maior grau.

A importância da diplomacia de cúpula não está ligada tanto ao aspecto protocolar e simbólico da participação do mandatário em política externa, mas principalmente:

"às expectativas que cria, à capacidade dos mandatários de alavancar ou não itens da agenda, à pressão política que eles são capazes de gerar com sua atuação e à autoridade e visibilidade que emprestam aos atos de que participam ou que referendam com a sua presença." (1999:70)

O autor ressalta que além da diplomacia de cúpula se definir como oposta à diplomacia tradicional, ela dá atenção a elementos que esta última não atenta, como a opinião pública, a ânsia por resultados, a projeção e a visibilidade em contraste com o anonimato dos diplomatas.

Dessa forma, Danese propõe (1999:63-4) vários graus para a diplomacia de cúpula:

\footnotetext{
${ }^{17}$ O autor descreveu (1999:87) como cânones da diplomacia tradicional ou diplomacia de estado a gestão discreta, a negociação reservada e o gesto sutil, em contraposição à diplomacia de cúpula, que ou é pública ou não existe como tal.
} 
- Grau zero: corresponde à diplomacia tradicional, protocolar;

- Primeiro grau: corresponde à uma diplomacia reativa, "reação à situação ou estímulos externos" e o mandatário é acionado para dirimir dúvidas, arbitrar diferenças, referendar propostas em ação (legitimando-as constitucionalmente). Danese esclarece que aqui o mandatário é uma "liderença no processo", "instância superior de decisão", e que há uma ação, mas como uma resposta, uma reação;

- Segundo grau: corresponde ao uso mais ativo pelo conjunto da diplomacia do instrumento diplomático em que o chefe de estado ou governo pode se transformar; "uma espécie de terreno privilegiado para o diálogo e transmissão de idéias, imagens, presença";

- Terceiro grau: corresponde a uma diplomacia afirmativa, na qual o mandatário toma a iniciativa, conduz pessoalmente a política externa segundo "sua própria sensibilidade e sendo de oportunidade, orientando a burocracia e assumindo politicamente, e não apenas administrativamente, a responsabilidade pela ação e pelos resultados".

Assim, por exemplo:

"Campos Sales visitou a Argentina em 1900 para retribuir a visita de Julio Roca ao Brasil. Foi um ato reflexo, reativo, de diplomacia presidencial brasileira; mas foi diplomacia presidencial, porque o grau zero, naquele momento, era uma condução estritamente protocolar e nominal da política externa brasileira pelo presidente; não era comum ou ordinário que se deslocasse ao exterior." (1999:63, nota 24)

Vê-se que em cada caso é importante ressaltar o que é considerado protocolar. Hoje por exemplo são uma exigência da globalização viagens presidenciais. Além disso, multiplicaram-se o número de eventos de cúpula no mundo, fazendo com que os presidentes sejam obrigados a cumprir uma intensa agenda.

Cabe aqui uma definição do que o autor considerou por protocolar. Um ato protocolar do presidente em política externa corresponde ao seu desempenho 
segundo as funções e responsabilidades prescritas na Constituição ou dela decorrentes. Seria um ato administrativo, nominal, que ele realiza enquanto chefe de uma burocracia de estado. Nesse sentido é algo obrigatório, impositivo, em termos de agenda e não opcional; produto do seu arbítrio e iniciativa.

Em suma, há itens de uma agenda de cúpula que são obrigatórios. Outros que são opcionais, dependem, portanto da iniciativa de cada mandatário. Assim, nem toda viagem presidencial é sinônimo de diplomacia presidencial. Uma viagem pode ser meramente obrigatória, mas os encontros paralelos a ela são opcionais. Um discurso numa sessão plenária pode ser obrigatório, mas o anúncio de uma decisão ou a proposta de uma iniciativa pode ter sido opção do mandatário. Apenas nesses últimos casos se faz diplomacia presidencial.

O autor enfatiza que diplomacia presidencial tem várias modalidades e não se resume à diplomacia de visitas e encontros. No seu modelo há três vertentes da diplomacia presidencial:

- a condução pessoal do processo decisório de política externa: essa condução deve ir além do protocolo. Danese complementa que essa atitude é uma combinação de alguns elementos: capacidade, interesse, conhecimento e sentido de oportunidade e urgência do mandatário em assuntos de política externa. E acrescenta que essa atitude é conseqüência também do comando do mandatário sobre a burocracia estatal encarregada de assuntos de política externa ${ }^{18}$.

- a diplomacia de iniciativas: o mandatário propõe e assume como suas as iniciativas de política externa. Essa vertente é na verdade resultado da primeira. Se incluí aqui a diplomacia de doutrinas, que são importantes na história diplomática e dão projeção a quem as propõe.

- diplomacia de encontros e deslocamentos: a proliferação desses encontros e deslocamentos no mundo é o "traço mais forte, visível e até preocupante" (1999:399) da diplomacia de cúpula. O autor elaborou (1999:407-412) uma tipologia das vertentes de visita de mandatário em

\footnotetext{
${ }^{18}$ Danese (1999:393) descreve essa burocracia estatal por: chancelaria, ministérios econômicos, forças armadas e agências governamentais que interagem de algum modo com o exterior.
} 
relação à modalidade de realização de cada uma: vertente política, parlamentar, cultural, etc., sendo que uma visita tem geralmente a combinação de alguns desses elementos.

Segundo Danese (1999:70), o que é considerado novidade na diplomacia presidencial é a intensidade e a generalização de seu uso como instrumento diplomático e de projeção interna dos mandatários. $O$ autor afirma que hoje ela ganhou preeminência entre as modalidades diplomáticas devido à:

"freqüência e abrangência com que se recorre à figura dos chefes de estado e governo para fazer diplomacia, em áreas, temas e situações em que, até há relativamente pouco tempo, era comum recorrer-se aos chanceleres ou a plenipotenciários."

Em relação às modalidades de diplomacia de cúpula, Danese afirma (1999:69) que a de visitas oficiais e de encontros de cúpula são as mais freqüentes. $A$ vertente de viagens e encontros bilaterais e multilaterais ganhou um lugar privilegiado, às vezes exagerado na execução da política externa da maioria dos países. Ela é vista como um instrumento diplomático que substitui ou complementa a diplomacia tradicional.

Para Danese, a diplomacia de cúpula opera em torno de dois eixos fundamentais: política interna e opinião pública, e política internacional (entendida aqui por sistema internacional e pelo modo de inserção do país no mesmo). A liderança política, que é uma das dimensões da diplomacia de cúpula, se efetua no cenário da política interna. O líder que faz diplomacia de cúpula se reporta constantemente às suas fontes de poder e age para engrandecer-se perante elas: forças partidárias, opinião pública, imprensa. "Seus atos têm origem e repercussão nessas fontes de poder e só têm sentido em função delas" (1999:87).

A opinião pública é um forte elemento, pois a diplomacia de cúpula moderna reage a ela, tentando cooptá-la ou impressioná-la, mas sempre dialogando com ela e com a política interna em geral (1999:90). Danese complementa que 
muitas vezes as decisões de política externa são tomadas levando-se em conta exclusivamente à opinião pública e os interesse de política interna.

Danese discute a idéia de que a diplomacia presidencial tenha tornado obsoleta a diplomacia tradicional. Para o autor isso não ocorre, pois o mandatário precisa da chancelaria, que mapeia o terreno no qual ele irá trabalhar, faz um trabalho de preparação e seguimento da atividade de cúpula. Entretanto, ele reconhece a existência de modalidades de diplomacia de cúpula feita com a marginalização dessa diplomacia tradicional, devido ou a urgência das iniciativas ou a problemas de coordenação entre o mandatário e a diplomacia, ou ainda por excesso de protagonismo deste e de sua assessoria direta (1999:81). Para Danese (1999:109), a diplomacia tradicional não se retraiu com a diplomacia de cúpula e sim aumentou o seu trabalho. Apenas houve uma queda da visibilidade que tinha anteriormente.

O cientista político Guilhon Albuquerque (1996:10) no artigo "A Presidência na linha de frente da diplomacia"19 afirma que o traço mais marcante do primeiro ano do governo Cardoso, como o título sugere, foi o fato da Presidência da República estar à frente da diplomacia.

O autor ressalta que o envolvimento deste presidente em política externa foi além do que convencionalmente se chama diplomacia presidencial. Então ele define o termo como:

"A participação pessoal do chefe do governo nas relações internacionais, seja por meio de pronunciamentos, seja de participação em foros internacionais, seja atuando diretamente em negociações".

Porém, para Guilhon Albuquerque o termo diplomacia presidencial tem baixo conteúdo conceitual, e o autor reforça a sua descrença, afirmando que se o presidente agisse como descreve o conceito, ele se tornaria apenas um "operador diplomático de primeira grandeza". Para ele o que se pode afirmar é

\footnotetext{
${ }^{19}$ Esse artigo foi publicado numa edição especial do boletim Carta Internacional (1996) sobre "Um ano de Política Externa do Governo FHC", donde há muitos outros artigos que mencionam o termo diplomacia presidencial (cf. Altemani, Lampreia, Genoíno, Cervo, Mourão).
} 
que no primeiro ano de governo de Cardoso houve uma disposição de concentrar na Presidência uma parte essencial da formulação de política externa.

Isso pode ser observado, segundo Guilhon Albuquerque, em relação às relações políticas internacionais desse governo, nas quais, em seus dois eixos principais - relações políticas com EUA e com Cone Sul - passam pelo "crivo direto das orientações presidenciais". O autor ressalta que nesses dois eixos, o fato do presidente ter influência direta não quer dizer que o Itamaraty só obedeça à instrução do Executivo. Entretanto, o que não pode ser negado é a presença das escolhas pessoais do presidente nesses casos. E exemplifica com as relações Brasil-Cone Sul, nas quais observa que "não há dúvidas de que as inclinações pessoais do presidente são parte da equação de qualquer ação diplomática do Itamaraty na região".

Conclui-se desse artigo, que Guilhon Albuquerque aponta temáticas na qual se percebe uma forte presença presidencial. Isto é, pode-se visualizar a marca das inclinações pessoais do presidente em algumas questões. Ele aponta as relações do Brasil com os EUA, com o Cone Sul (especialmente Argentina) e com a Organização das Nações Unidas (ONU). Porém, ele ressalta que isso não significou uma retração da ação do Itamaraty.

Para o autor, constata-se uma convivência entre presidente e Itamaraty em relação à influência sobre a política externa. Nesse sentido, cabe ao presidente uma parte essencial da formulação da política externa.

O autor não afirma que essa presença do presidente em torno das questões citadas significam diplomacia presidencial. Vê-se isso quando ele afirma que o envolvimento do presidente em política externa "vai além do que se convencionou chamar de diplomacia presidencial"20. Mais uma vez ele não se compromete com o conceito.

\footnotetext{
${ }^{20}$ Grifos meus.
} 
Guilhon Albuquerque aponta que alguns temas, por exemplo, a ONU, sofrem as "vicissitudes dos presidentes", ou seja, o modo como esses temas são tratados na política externa reflete as personalidades $e$ as agendas presidenciais. Para 0 autor a presença do presidente do Brasil no relacionamento com a ONU não foi antes tão perceptível, porque o objetivo central dessa política - acesso do Brasil ao Conselho de Segurança como membro permanente - vem sendo perseguido desde o governo Sarney. As vicissitudes mencionadas acima se referem ao fato dessa política estar no primeiro plano no governo Collor e depois "voltar ao limbo" no governo Itamar, sendo que no governo Cardoso foi considerada prematura e secundária. Porém, ele mudou de atitude com o tempo, dando atenção especial a essa questão.

Guilhon Albuquerque analisa em outro artigo "O alcance da diplomacia presidencial" (1997) a visibilidade da diplomacia presidencial nos dois primeiros anos da gestão Cardoso.

Nesse artigo, o autor expôs várias características (descritas abaixo) atribuídas a esse conceito, questionando a utilidade das mesmas. $O$ artigo termina com um exemplo do que se qualificaria como um ato de diplomacia presidencial.

Guilhon Albuquerque se pergunta se a diplomacia presidencial equivale à atuação externa pessoal do presidente e também se esta equivaleria à formulação de políticas inovadoras e a operação direta das mesmas. Se ela corresponde à formulação de políticas inovadoras e a sua operação direta, dificilmente poderíamos empregar o conceito de diplomacia presidencial para caracterizar as viagens presidenciais ou a participação do presidente Fernando Henrique Cardoso em reuniões do Conselho do Mercosul ou na Assembléia Geral da Organização das Nações Unidas.

Para o autor um bom exemplo do presidente fazendo diplomacia presidencial poderia ser a intervenção do presidente Cardoso na tentativa de golpe do Paraguai, mas a seguir coloca em dúvida a possibilidade de se fazer tal afirmação, alegando que o presidente poderia ter agido neste caso como 
qualquer diplomata, seguindo instruções e não com autonomia. Para testar este exemplo seria necessário maiores informações e análises mais aprofundadas.

Por tudo isso o autor chamou a diplomacia presidencial de "decantada diplomacia presidencial", além de manter a expressão no texto sempre entre aspas, denotando a sua crítica quanto a possibilidade de emprego criterioso do termo, já que ele, na palavras do autor, "ainda carece de uma definição mais precisa".

No mesmo ano da publicação do artigo de Guilhon Albuquerque, Nuñez (1997) publica o artigo "La diplomacia presidencial", com uma abordagem bem mais positiva. Para analisar esse conceito, o autor toma como exemplo as relações bilaterais Brasil-Argentina, especialmente no âmbito do Mercosul.

Nesse artigo o autor não chega a definir conceitualmente o que significa a diplomacia presidencial, somente expõe que:

"Na década de oitenta se inicia na América um processo que caracteriza uma nova tipologia de relações internacionais: a diplomacia presidencial. $\mathrm{Na}$ década de noventa, a diplomacia presidencial cobra novas forças constituindo-se num eixo constante e permanente da expressão da vontade integracionista." (1997:133)

Para reforçar este argumento o autor cita o aumento da intensidade das relações bilaterais Brasil-Argentina. Para o autor, foi relevante o fato de em 1997 os presidentes Fernando Henrique Cardoso e Menem terem inúmeros encontros, tanto de reuniões de cúpula, quanto bilaterais.

Esse artigo utiliza o termo diplomacia presidencial como sinônimo de encontros presidenciais. $O$ termo está também restrito à análise das relações bilaterais Brasil-Argentina, mais especificamente em relação ao Mercosul. Quando ele qualifica as características mais importantes da diplomacia presidencial, o faz apenas em relação a este processo de integração. 
Por exemplo, o autor tirou a média dos encontros presidenciais entre Brasil e Argentina em 1997, resultando numa freqüência de um encontro a cada mês e meio. A partir desse dado, ele apontou a novidade desse ativismo presidencial nas relações internacionais sub-regionais. Isso considerando, segundo o autor, que do começo do século até 1950, os presidentes haviam se reunido uma única vez.

No caso específico das relações Brasil-Argentina, Nuñez indica um novo componente da diplomacia presidencial, que a caracteriza nos dois últimos anos (1996 e 1997): as reuniões de cúpula presidencial, seguidas pelas reuniões binacionais de gabinete. Ele atribui o início dessa prática à visita de estado de Fernando Henrique Cardoso em 1996, que foi seguida pela reunião de fronteira, no mesmo ano e em 1997 com Carlos Menem visitando o Brasil.

Até então, o costume era que nas Relações Internacionais as reuniões de cúpula de chefes de estado representavam uma oportunidade para concluir acordos sobre temáticas que a diplomacia tradicional havia traçado, observa Nuñez. Hoje, os mandatários nos encontros é que instruem suas administrações sobre temas novos que devem ser trabalhados. É essa a principal característica da nova diplomacia presidencial que o autor apontou. Contudo, Nuñez esclarece que a diplomacia presidencial não desvaloriza as chancelarias e os órgãos de integração, que têm a responsabilidade primária na construção da política externa e na gestão do processo de integração, respectivamente.

Nuñez observa que até abril 1997 as agendas presidenciais bilaterais se concentravam em questões comerciais. Uma vez superados os principais conflitos comerciais, a agenda presidencial pôde incorporar novos temas. Começou-se então a discutir o aprofundamento do Mercosul. O autor afirma (1997:136) que a 'nova diplomacia presidencial' prepara as administrações nacionais para incorporarem na sua agenda questões novas. Isso contribuiu para o avanço na concretização do Mercosul. 
Ele afirma que a diplomacia presidencial cumpre outro papel de grande importância:

"a reafirmação permanente da vontade de nossos governos de estabelecer regras de jogo estáveis e maduras no contexto da integração, como também dar um renovado impulso às obras de integração física e a simplificação dos trâmites na fronteira." (1997:138)

O autor qualificou também a diplomacia presidencial como "convocante" e "interativa", pois ela propõe e recebe propostas da sociedade, como por exemplo, dos empresários argentinos e brasileiros ${ }^{21}$.

Após analisar a experiência Brasil-Argentina, Nuñez conclui que a nova diplomacia presidencial propõe os grandes caminhos que o Estado deverá percorrer e instrui às administrações nacionais para avançar em temas novos, além de reafirmar as políticas traçadas. Essas características geram um maior diálogo e uma maior confiança na sociedade. Para o autor, a participação dos chefes de Estado no processo de integração é uma característica básica dessas negociações, no qual as populações estariam construindo uma nova identidade, uma nova cultura e uma nova forma de soberania.

O também argentino Malamud (2005), cientista político do "Centro de Pesquisa e Estudos de Sociologia" de Lisboa escreveu um artigo sobre Diplomacia Presidencial e Mercosul.

Para ele diplomacia presidencial é:

"um mecanismo entendido como um recurso para dirigir as negociações entre os presidentes, sempre que uma decisão crucial precisa ser feita ou um conflito crítico necessita ser resolvido (...) compreendida como uma diplomacia política, de cúpula, oposta a diplomacia institucionalizada, profissional." (2005:138)

Nesse artigo, ele sustenta que é lugar comum afirmar que o Mercosul tem se apoiado na diplomacia presidencial, citando Danese e Nuñez. Mas o autor vê essa questão de um ângulo diferente de Nuñez. Para ele o que alavanca o

\footnotetext{
${ }^{21}$ Ele se refere (1997:138) ao Consenso de São Paulo (11 ${ }^{\text {a }}$ Assembléia Geral da Conferência das Nações Unidas sobre Comércio e Desenvolvimento - Unctad), na qual os presidentes do Brasil e da Argentina escutaram recomendações dos empresários de ambos países.
} 
processo de integração não é a diplomacia presidencial. Ele considera que o argumento de diplomacia presidencial não está incorreto no caso do Mercosul, mas não provê uma explicação verdadeira dos procedimentos e resultados do bloco.

A hipótese do autor é que as estruturas institucionais, formadas pelo sistema de governo dos países membros do Mercosul é que têm sustentado à intervenção presidencial e o processo de integração regional. E não a diplomacia presidencial.

Em seu artigo Malamud analisou três estudos de caso para testar essa hipótese: as controvérsias sobre regimes especiais, o caso do automóvel e do açúcar e a crise de 1999 da desvalorização monetária.

O autor aponta que o desempenho dos presidentes dos países membros do Mercosul - que têm exibido autonomia no decision-making do bloco - tem sido formado pelos incentivos e por alguns constrangimentos institucionais. Assim, o alto grau de concentração de poder nas mãos dos chefes do Executivo os capacita a vencer potenciais atores com poder de veto - como o gabinete ministerial e o Congresso. Além disso, a política externa tipicamente oferece aos chefes do Executivo maior margem de manobra que as políticas domésticas.

Outras razões, segundo o autor, adicionais aos recursos institucionais já nas mãos do chefe do Executivo, ajudam a explicar o alto grau de manobra dos presidentes. Entre elas: a tradição da supremacia do Executivo em política doméstica, a frágil institucionalização do Mercosul (sem atores com poder de veto para bloquear as intervenções presidenciais) e a ausência ou fraca participação de atores sociais relevantes (como por exemplo, as organizações empresariais).

Malamud afirma que os presidentes são eficazes na resolução de crises. E isso ocorre não meramente devido a sua liderança carismática, mas também as 
suas capacidades institucionais. O autor prova o seu argumento através da análise dos três estudos empíricos, como já foi apontado.

Um desses estudos de caso é a primeira crise do açúcar de 1997. Foi criado um comitê ad-hoc do Mercosul para estabelecer o regime especial do açúcar. Entre 1995 e 1997 a Argentina questionou os subsídios ao açúcar brasileiro e em 1997 o Congresso argentino criou uma lei, na qual a tarifa ao açúcar brasileiro seria igual a dos país não membros do bloco. Tal lei foi vetada pelo então presidente Menem. O Senado argentino, por sua vez, rejeitou o veto executivo. A solução encontrada para essa crise pelo presidente argentino foi acatar, porém, nunca aplicar a lei de tarifa ao açúcar brasileiro. Com esse exemplo, o autor mostrou o domínio do presidente sobre o Congresso, ou seja, a força do ativismo presidencial no Mercosul, propiciada pelas características institucionais dos seus presidentes.

O autor aponta, na sua conclusão, que a diplomacia de cúpula não é uma característica exclusiva do Mercosul, a originalidade deste reside no fato dele ser o mais significativo bloco regional cujos países membros são todos presidencialistas, e cujas instituições regionais são pouco significativas. Malamud complementa que a intervenção presidencial na condução do Mercosul tem se tornado um elemento estrutural do processo de integração.

O artigo de Rojas \& Milet $(1999)^{22}$, dois pesquisadores da área de Relações Internacionais da Flacso-Chile, versa sobre o processo de inserção internacional da América Latina. Para os autores, as relações dos países latinoamericanos se manifestam tanto em organismos multilaterais tradicionais, quanto no desenvolvimento de uma intensa diplomacia presidencial, organizada em cúpulas presidenciais.

\footnotetext{
22 Há outros trabalhos que analisam especificamente a modalidade da diplomacia presidencial de encontros de cúpula entre chefes de estado e de governo, e não a diplomacia presidencial em termos gerais. Por isso não foram analisados aqui, exceto Rojas \& Milet (1999), que serve como exemplo dessas publicações. Conferir Melissen (2003), Sol (2004), Peña (2005), Andrés Malamud (2005b), Rojas (2005) e Carlos Malamud (2005).
} 
Porém, para os autores citados reuniões de cúpula são sinônimo de diplomacia presidencial:

"A diplomacia de cúpula está diretamente vinculada à diplomacia presidencial. De certa forma, a diplomacia de cúpula procura ser uma síntese da representação estatal e, nesse sentido, desenvolver o relacionamento entre soberanos, com a representação popular que cada chefe de estado possui (...) No pós-guerra fria, o multilateralismo adota novas formas: a diplomacia de cúpulas. Esta se diferencia da diplomacia tradicional de caráter parlamentar, fundamentalmente, porque nela é a 'diplomacia presidencial' que adquire espaço substantivo." (1999:311)

Assim, concluem que a diplomacia presidencial é um dos principais elementos da política externa da América Latina: “... formalizada na diplomacia de cúpulas, transforma-se, no final do século XX, em um dos principais elementos da política externa e dos intercâmbios diplomáticos do tipo regional, subregional e multilateral da América Latina" (1999:352).

Há dois trabalhos de pós-graduação que merecem ser mencionadas aqui, e que exemplificam como a diplomacia presidencial se tornou recorrente nos debates tanto na mídia, quanto nos meios acadêmicos. De fato esse tema se tornou comum nas análises de política externa a partir da gestão Cardoso e agora da gestão do presidente Luiz Inácio Lula da Silva. ${ }^{23}$

Primeiramente se tratará aqui da dissertação de mestrado de Cerqueira (2005). Nesse trabalho foi abordado especificamente o tema diplomacia presidencial, analisando-se a presença do termo na imprensa escrita.

Na seqüência se analisará a tese de doutorado de Ayllón (2004). Esse trabalho não teve a diplomacia presidencial como foco principal. Entretanto, ela foi um tema recorrente na tese. Também o foi em outro artigo desse autor, para reforçar a questão.

\footnotetext{
${ }^{23}$ Há uma dissertação de mestrado sendo desenvolvida no Programa de Pós-graduação em Ciência Política do Instituto de Filosofia e Ciências Humanas da Universidade Estadual de Campinas sobre as relações internacionais e a política externa brasileira nos governos Cardoso e Lula, na qual a autora aborda a diplomacia presidencial de ambas gestões. Cf. Sales, 2006.
} 
Cerqueira (2005) examina em sua dissertação de mestrado a diplomacia presidencial dos dois mandados de Cardoso e a sua intensa cobertura pela imprensa escrita. Para o autor, alguns veículos da imprensa escrita tiveram autonomia como ator político doméstico para influenciar a formulação da política externa brasileira do período. Isso ocorreu porque a agenda intensa do presidente se tornou pauta nos jornais. Com isso os temas de política externa ganharam visibilidade na opinião pública.

Para Cerqueira, os objetivos da diplomacia presidencial na gestão Cardoso foram: servir de ferramenta à inserção internacional do Brasil, dar impulso às relações entre países e comprometer as burocracias estatais com 0 cumprimento de metas. Ela teve como efeito atrair a atenção da sociedade para assuntos relacionados à política externa. Essa atenção ocorreu (o autor ressalta que foi o fator principal e talvez o único) via cobertura da imprensa aos eventos que envolveram o presidente da República.

O Itamaraty por sua vez utilizou a diplomacia pública como estratégia de ação. A diplomacia presidencial foi sua face mais notória no plano externo ${ }^{24}$, e a retórica do diálogo com a sociedade a sua face interna mais reforçada (2005:47). O corpo diplomático via na pessoa de Cardoso qualidades apropriadas para que ele desempenhasse com êxito a diplomacia presidencial: seu renome internacional como intelectual, sua experiência em política externa e "o próprio déficit de diplomacia presidencial que o Brasil tinha então" (2005:56).

O autor aponta que a diplomacia presidencial como estratégia de inserção internacional ${ }^{25}$ foi uma escolha do Itamaraty e coloca o seu aspecto negativo (2005:47):

\footnotetext{
24 "Em pronunciamentos de seus mais altos representantes, o conceito era enfatizado, explicado e defendido como essencial para a inserção internacional do Brasil (...) são muitos os pronunciamentos em que o Itamaraty explicita as razões para o uso da diplomacia presidencial e os objetivos perseguidos com a utilização dessa ferramenta" (2005:56). O autor dá exemplos desses discursos, cf. 2005:56-7.

${ }^{25} \mathrm{O}$ governo Cardoso se inicia confrontado com a necessidade de estabelecer um novo modelo de inserção internacional para o Brasil, devido à crise das polaridades indefinidas. O presidente traz para o Ministério das Relações Exteriores o embaixador Luiz Felipe Lampreia, que inicia sua gestão reforçando
} 
"Forma sem conteúdo, essa ferramenta diplomática tinha a vantagem de servir a vários interesses e objetivos, cambiáveis ao longo do tempo, e cuja definição dependeria do debate interno a que a chancelaria se dizia aberta."

Complementando em seguida com seu aspecto positivo:

"Ainda que diversos grupos sociais possam não ter obtido êxito na barganha doméstica em função do caráter excessivamente retórico da diplomacia pública implementada, a opção pelo protagonismo de Cardoso em política externa gerou um debate do qual participaram a chancelaria, a imprensa, analistas de política externa e outros formadores de opinião."

O MRE tentava justificar a intensa agenda internacional de Cardoso "por desígnios próprios da política internacional contemporânea e pelos benefícios econômicos e políticos que a atuação do mandatário poderia proporcionar ao país" (2005:58).

O esforço do Itamaraty concentrou-se em fomentar o debate interno dentro dos parâmetros que garantissem apoio e legitimidade a suas iniciativas. Para isso, a diplomacia presidencial teve valor fundamental, já que o Itamaraty buscava valer-se da cobertura da imprensa para transmitir a boa receptividade que Cardoso tinha no exterior ao público interno e reforçar as escolhas da chancelaria na arena internacional para a opinião pública e para a sociedade. Entretanto, o esforço oficial nem sempre foi bem sucedido. Ainda que o Itamaraty tenha mantido o controle sobre a formulação da política externa, o uso da diplomacia presidencial tornou público o debate sobre o processo (2005:52).

O autor utiliza a definição de diplomacia presidencial de Danese (2005:91); Cerqueira nota que segundo essa definição, a diplomacia presidencial não se refere apenas a questões meramente rotineiras da função do mandatário, e sim a um conjunto de iniciativas que fazem do presidente o principal condutor da política externa.

o discurso da diplomacia pública como necessidade dos países democráticos frente aos novos desafios do cenário internacional e apontando como ferramenta apropriada ao Brasil à diplomacia presidencial (2005: 51). 
Para o autor (2005:92-3) a postura de liderança do mandatário tem conseqüências políticas também internamente. O presidente se utiliza de elementos que são alheios à rotina da burocracia diplomática; a opinião pública, o equilíbrio político doméstico e a visibilidade aos assuntos de política externa em função da participação direta do presidente.

Na conclusão, Cerqueira afirma (2005:93) que a diplomacia presidencial não é uma constante na história republicana do Brasil. Nem todos presidentes a utilizaram, devido a constrangimentos externos ou a razões do cenário político interno; ou ainda por causas de características próprias da personalidade do presidente. O autor (93-4) aponta que com o Barão de Rio Branco no Itamaraty os presidentes só cumpriram funções protocolares. Já com o Juscelino Kubitschek (principalmente com a Operação Pan Americana) a diplomacia presidencial foi usada intensamente. Por sua vez, na gestão de Cardoso a condução da política externa foi um traço marcante de seu governo.

A tese de doutorado de Ayllón (2004) analisou as relações (políticas, econômicas e culturais) entre Brasil e Espanha, a partir da perspectiva da política externa brasileira, no período de 1979 a 2000. O que interessa ao presente trabalho é especificamente 0 item ${ }^{26}$ em que ele analisa a diplomacia presidencial de Cardoso com objetivo de examinar a ação desse estadista sobre as forças profundas ${ }^{27}$ no plano externo, através de sua ação políticodiplomática, potencializada pela diplomacia presidencial. Para o autor a diplomacia presidencial foi o elemento chave das relações hispano-brasileiras.

Segundo Ayllón, Cardoso fez diplomacia presidencial pois “...su fama de intelectual versátil [imprimiu] un sello personal a las relaciones internacionales de Brasil" (2004:384). Segundo o autor, a política externa brasileira na sua gestão teve a sua "marca", já que ele as conduzia pessoalmente e um dos motivos para tal foi seu histórico intelectual conhecido internacionalmente.

\footnotetext{
${ }^{26}$ Refere-se ao item "7.1.2- La importancia de la diplomacia presidencial: el papel de Cardoso" (Ayllón, 2004:381).

${ }^{27} \mathrm{O}$ autor utiliza as categorias forças profundas e homem de estado de Duroselle, cf. cap.3, p. 78 dessa dissertação.
} 
Cardoso possuía habilidade diplomática, prestígio internacional como intelectual estudioso dos problemas do desenvolvimento e da inserção de países periféricos na Economia Internacional. Essa imagem de Cardoso contribuiu para aumentar a atenção do mundo em relação ao Brasil (2004:384).

Para Ayllón (2004:383) é complicado compreender o projeto diplomático de Cardoso sem fazer referência ao Plano Real. Esse plano foi um fator decisivo na primeira eleição do presidente (outubro de 1994) e na sua reeleição (outubro de 1998). Além desse êxito interno, externamente Cardoso contava com o apoio e simpatia da comunidade internacional.

Ayllón aponta (2004:384-5) que as viagens de Cardoso representam um exercício de diplomacia de chefes de estado no âmbito bilateral e multilateral ("prática comum entre os Estados, característica das Relações Internacionais das últimas décadas"). E também uma estratégia deliberada para mostrar e atualizar a presença exterior do Brasil no mundo perante a opinião publica, com base nos avanços do país em relação ao processo de consolidação democrático e a estabilização e abertura econômica.

Assim, o autor constata que a diplomacia presidencial tem no governo de Cardoso 3 características importantes:

- Objetiva projetar a imagem do Brasil no exterior; visando à opinião pública nacional e internacional;

- o presidente formula os objetivos de política externa;

- o presidente executa diretamente a política externa ${ }^{28}$.

O autor conclui (2005:385-6) que a diplomacia presidencial foi funcional para o estabelecimento de novas "parcerias" estratégicas e um instrumento válido para que o Brasil alcançasse uma posição favorável em sua interação com o mundo. Os fatos que permitem ao autor comprovar sua observação são: qualidade do diálogo promovido pelas visitas de Cardoso à Espanha;

\footnotetext{
${ }^{28} \mathrm{Na}$ descrição dessas características o autor citou um trabalho não publicado de GUILHON, J.A.: “A política externa do governo Fernando Henrique", Seminario NUPRI-USP, 24 de maio de 2002.
} 
capacidade do presidente brasileiro de transmitir os traços principais da nova realidade brasileira, e empenho com que se apresentava e defendia os pleitos brasileiros. Esse ativismo presidencial estabeleceu um novo tipo de relação com a Espanha.

Outro trabalho de Ayllón (mimeo), uma resenha do livro de Danese (1999) intitulado "Entre presidentes está el juego...diplomático" contribui para a compreensão da visão de Ayllón sobre a diplomacia presidencial.

Para o autor, o papel da diplomacia presidencial como um poderoso instrumento de aproximação, fortalecimento e intensificação das relações entre países representa a característica mais relevante na dinâmica recente das Relações Internacionais. Ainda que esse não seja o único instrumento de que dispõem as burocracias.

Ayllón expõe 2 argumentos contrários à diplomacia presidencial:

1- sua instrumentalização política como forma de legitimar internamente medidas de governo protegidas por sua aprovação no exterior.

2- Excesso de viagens presidenciais e o acentuado personalismo desta diplomacia confundindo a esfera pessoal com os interesses nacionais.

O autor afirma que apesar das críticas, as evidências empíricas demonstram a intensificação e o aumento das viagens de altos mandatários, a celebração cada vez mais freqüente de reuniões de cúpula diplomáticas, o formato variado que esses encontros adotam e seus resultados concretos.

Notemos que todos trabalhos, exceto o de Danese, analisam a prática da diplomática ou político-diplomática da diplomacia presidencial e não o seu aspecto conceitual. Isso porém não minimiza a análise desses trabalhos, pois a maioria dos autores, antes de explicar a diplomacia presidencial enquanto prática, a descreve, caracterizando-a e, por vezes, conceituando-a. Daí é que 
se procurou derivar a análise do seu aspecto conceitual.

Essa descrição da diplomacia presidencial foi feita pelos autores ao abordarem por exemplo, uma característica que atribuíram ao termo ou mesmo a situação na qual a prática se concretizou. Esses elementos fornecem indícios de como os autores que não definiram expressamente diplomacia presidencial a interpretaram. Com base nesses elementos elaborou-se um quadro da literatura que abordou o tema e que pode ser observado na tabela "Principais referências teóricas sobre o conceito de diplomacia presidencial".

O próximo item consiste numa análise comparativa dessa literatura, que foi realizada através da tabela citada.

\subsection{ANÁLISE COMPARATIVA DA LITERATURA}

Esse item estabelece comparações entre as publicações vistas no item anterior. Serão analisados o que elas têm em comum ou em desacordo e como abordam o tema, se pelo viés da prática político-diplomática ou do conceito, ou de ambos. Uma tabela foi elaborada para comparar essas obras de referência e a discussão da literatura foi feita tomando-a como base. 


\begin{tabular}{|c|c|c|c|c|c|c|c|c|c|}
\hline \multirow{11}{*}{ 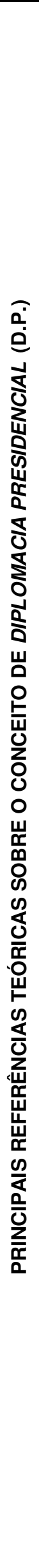 } & $F$ & 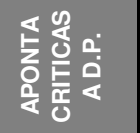 & $\frac{E}{\omega}$ & $\frac{\stackrel{\pi}{z}}{2}$ & $\frac{E}{\omega}$ & $\frac{\stackrel{0}{z}}{2}$ & $\frac{E}{\omega}$ & $\frac{\text { iा }}{20}$ & $\frac{E}{\omega}$ \\
\hline & 우 & 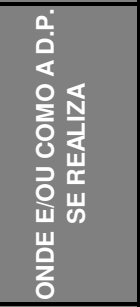 & 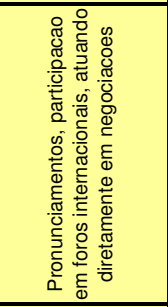 & 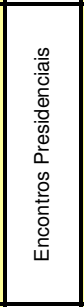 & 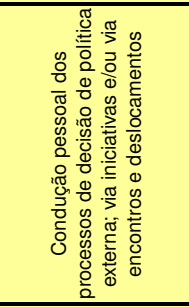 & 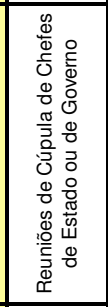 & 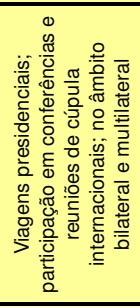 & 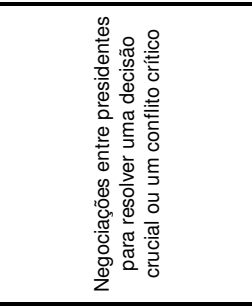 & 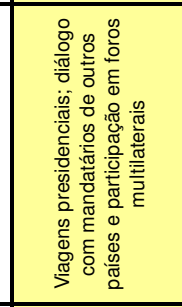 \\
\hline & $\sigma$ & $\begin{array}{l}\frac{\pi}{0} \\
\frac{1}{4}\end{array}$ & 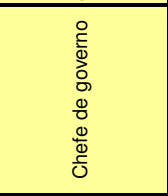 & 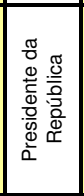 & 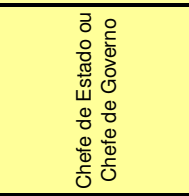 & 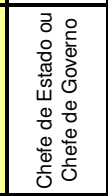 & 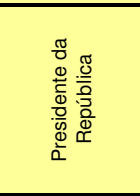 & 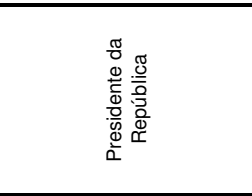 & 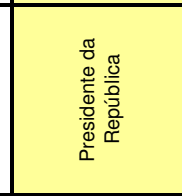 \\
\hline & $\infty$ & 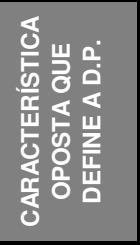 & & 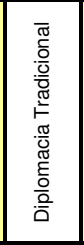 & 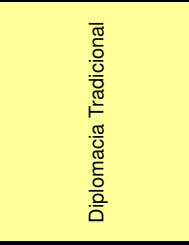 & 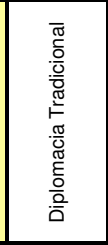 & & 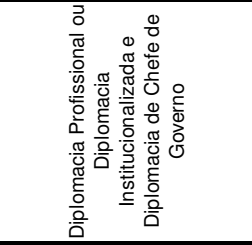 & 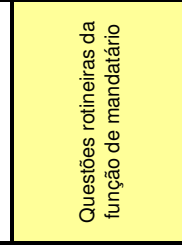 \\
\hline & $\wedge$ & 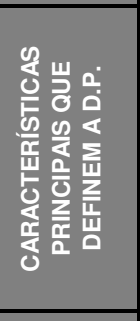 & 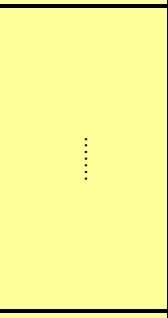 & 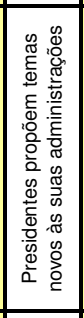 & 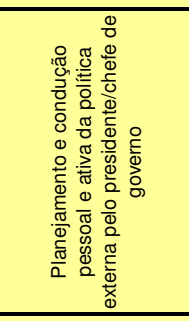 & 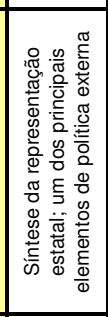 & 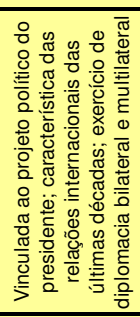 & 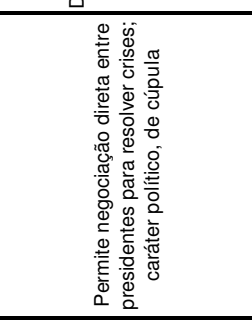 & 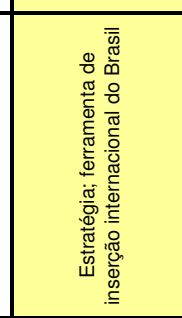 \\
\hline & & 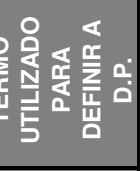 & $\vdots$ & 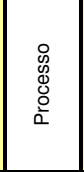 & 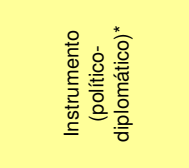 & 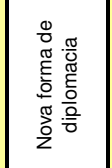 & 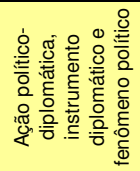 & 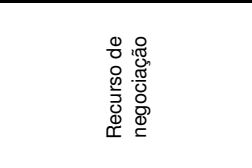 & 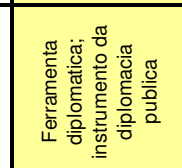 \\
\hline & in & 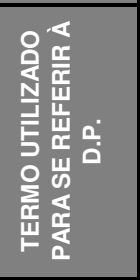 & 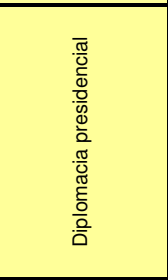 & 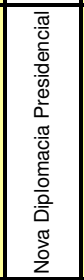 & 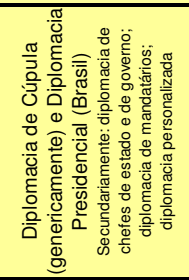 & 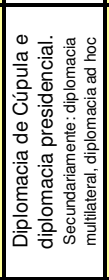 & 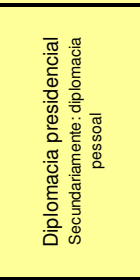 & 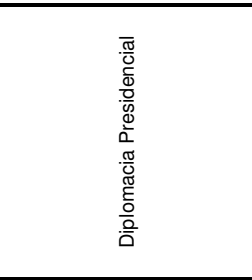 & 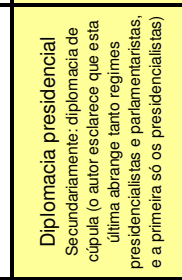 \\
\hline & $\nabla$ & 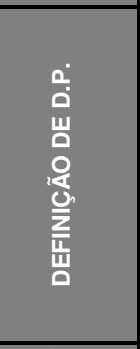 & 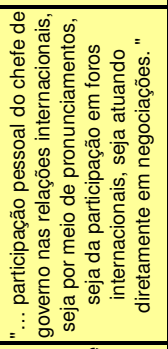 & $\vdots$ & 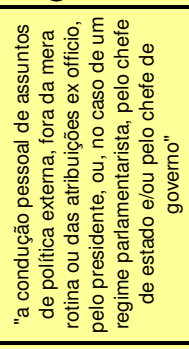 & $\vdots$ & & 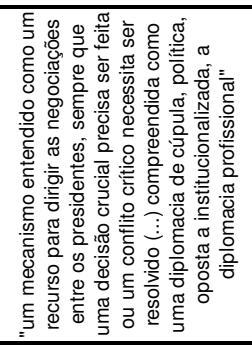 & 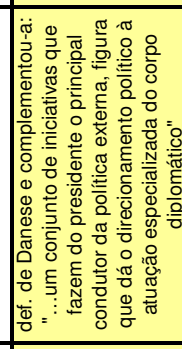 \\
\hline & $m$ & 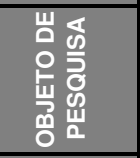 & 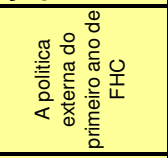 & 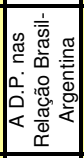 & 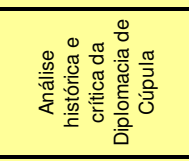 & 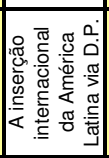 & 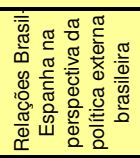 & 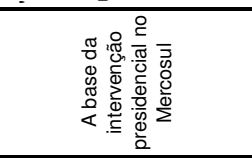 & 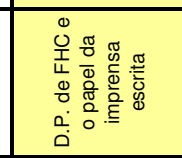 \\
\hline & $\sim$ & 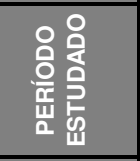 & 兽 & 兽 & 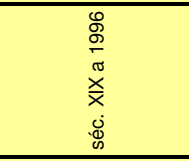 & 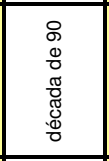 & 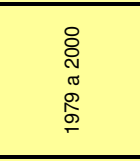 & 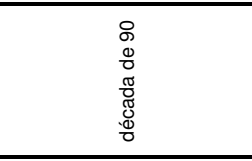 & 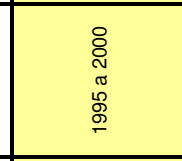 \\
\hline & & 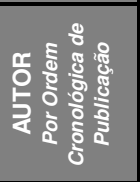 & 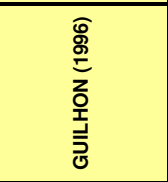 & 旁呑 & 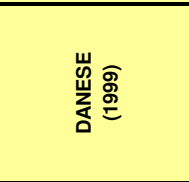 & 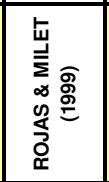 & 䓛 & 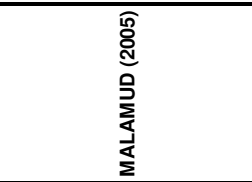 & 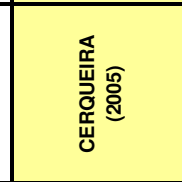 \\
\hline
\end{tabular}


Um ponto importante aqui é observar quais trabalhos definem a diplomacia presidencial e quais não o fizeram (cf. item definição de diplomacia presidencial, coluna 4), pois isso contribui para a compreensão do estatuto teórico do conceito, ainda indefinido. O único trabalho com preocupação conceitual é sem dúvida o de Danese, os outros analisaram a diplomacia presidencial enquanto prática político-diplomática e não enquanto conceito. Observa-se também que praticamente todos autores concordam - exceto Ayllón e Guilhon Albuquerque, que não afirmam isso - que a diplomacia presidencial é oposta à diplomacia tradicional ${ }^{29}$ ( cf. coluna 8).

É lógico que não se pode analisar esse conceito sem se fazer referência a sua prática, mas o contrário é verdadeiro (Nuñez, Rojas \& Milet, Ayllón). A maioria dos trabalhos que definem diplomacia presidencial fazem referência à obra de Danese, alguns utilizam a sua própria conceitualização (Malamud, Guilhon Albuquerque, Cerqueira). Cerqueira utiliza a definição de Danese e complementa com a sua. Apesar de poucos terem elaborado uma definição teórica, no decorrer do texto, ao descreverem a diplomacia presidencial, dão indícios de como a interpretaram. Derivamos isso pelos termos utilizados para se referir à diplomacia presidencial, pelas características que atribuíram a ela, por quem consideraram o ator da diplomacia presidencial, pelo local e âmbito onde ela se realiza e, por fim, pela sua postura em relação à diplomacia presidencial, ou seja, se estabelecem críticas ou não (colunas de 6 a 11). A análise de cada um desses termos vem a seguir.

Em relação ao período estudado (coluna 2) todos os trabalhos referem-se à década de 90. Alguns abordam um período anterior a ela, mas a incluem. Isso se deve ao fato da origem do termo diplomacia presidencial ter surgido na literatura brasileira na década de 90, pois foi no início da gestão Cardoso que o tema apareceu com força na literatura.

Quanto ao objeto de pesquisa (coluna 3), somente para Danese e Cerqueira a diplomacia presidencial é o tema central. Para o restante ela é um tema

\footnotetext{
${ }^{29}$ Conferir definição de protocolo na p. 35-6 dessa dissertação.
} 
secundário. Como já foi mencionado, há muitas referências à diplomacia presidencial dentro de análises da política externa de Cardoso. Assim, todas as publicações aqui apresentadas mencionam a gestão Cardoso. Em algumas publicações ela é parte do objeto de pesquisa diretamente (Guilhon Albuquerque, Danese, Cerqueira), em outras, o é indiretamente (Nuñez, Rojas \& Milet, Malamud, Ayllón,).

Em relação à escolha do termo empregado para se referir à diplomacia presidencial (coluna 5), alguns autores usam o termo nova diplomacia presidencial $(\mathrm{Nuñez})^{30}$, diplomacia pessoal (Ayllón) ou diplomacia personalizada (Danese); diplomacia de cúpula (Danese, Rojas \& Milet, Cerqueira) ou diplomacia de chefes de estado ou de governo (Danese) ou ainda diplomacia de mandatários (Danese), outros utilizaram diplomacia presidencial (Malamud, Danese, Ayllón, Cerqueira).

Pelo fato da diplomacia presidencial se referir a regimes presidencialistas, alguns autores optaram por usar o termo diplomacia presidencial (Malamud, Danese, Ayllón, Cerqueira). Nota-se que a escolha quanto ao uso do termo dá indícios de como o autor conceitualiza a diplomacia presidencial. Se a coloca entre aspas em todo o texto, como Guilhon Albuquerque (1997), denotando que não adere ao seu uso, se utiliza diplomacia de cúpula, indicando regimes presidencialistas e parlamentaristas (Danese); ou porque refere-se somente a modalidade de reunião de cúpula (Rojas \& Milet).

Pode-se notar que Rojas \& Milet usam o termo diplomacia de cúpula de modo diferente de Danese. Para esse último a diplomacia de cúpula é sinônimo de diplomacia de mandatários, e, portanto, se refere tanto aos chefes do Executivo do Parlamentarismo quanto do Presidencialismo. Também para Danese, a diplomacia presidencial não se refere somente a reuniões de cúpula, mas a várias outras situações onde ocorre o uso deste instrumento políticodiplomático ${ }^{31}$.

\footnotetext{
${ }^{30}$ Nuñez passou a referir-se a diplomacia presidencial no decorrer do artigo como 'nova' diplomacia presidencial depois de ter citado os novos elementos desta. Conferir p. 42 dessa dissertação.

${ }^{31}$ Conferir descrição dessas outras situações na p. 36-7 dessa dissertação.
} 
Já para Rojas \& Milet, a diplomacia de cúpula é sinônimo de reuniões de cúpula. Ou seja, a definição dos autores se restringe às situações de reuniões de cúpula de chefes de estado e de governo ${ }^{32}$. Eles não mencionam as outras situações - descritas por Danese ${ }^{33}$ - onde pode ocorrer a diplomacia de cúpula, como a condução pessoal do processo de política externa e a diplomacia de iniciativas. Além disso, dentro da vertente de encontros e deslocamentos, na qual estão as reuniões de cúpula de chefe de estado e de governo há uma variada tipologia, que não se restringe portanto a esse tipo de reunião.

Para Malamud a diplomacia presidencial é conceitualmente diferente da prática desenvolvida pelo primeiro ministro nos regimes parlamentaristas. Por isso ele advoga usar termos diferentes para cada sistema de governo. Desse ponto de vista ele difere de Danese, para quem o termo diplomacia de cúpula e diplomacia de mandatários engloba os chefes do Executivo dos dois sistemas de governo.

Danese usa no seu livro o termo diplomacia de cúpula para se referir genericamente ao conceito, incorporando tanto chefes de estado, quanto de governo ${ }^{34}$; já diplomacia presidencial utiliza para se referir especificamente aos presidentes. Além disso, utiliza - com menos freqüência - outros termos no decorrer do livro: diplomacia personalista, diplomacia de chefes de estado ou de governo e diplomacia de mandatários.

No entendimento desse trabalho, a diplomacia presidencial está contida na diplomacia de cúpula, que é o termo mais genérico. Assim, tomou-se como base a definição de Danese: uso do termo diplomacia presidencial para

\footnotetext{
${ }^{32}$ Nota-se que quando as reuniões são especificamente de cúpulas presidenciais, os autores utilizam o termo diplomacia presidencial (2005:292).

${ }_{33}^{33}$ Conferir descrição dessas outras situações na p. 36-7 dessa dissertação.

${ }^{34} \mathrm{O}$ chefe de estado possui um papel representativo, simbólico; já o chefe de governo tem representatividade política, ele é o chefe do Executivo. Num regime presidencialista a mesma pessoa representa as duas funções, no parlamentarista republicano o chefe de estado é o presidente e o chefe de governo o primeiro ministro e no parlamentarista monárquico o chefe de estado é o monarca e o chefe de governo é o primeiro ministro.
} 
regimes presidencialistas, especificamente, e de diplomacia de cúpula para regimes presidencialistas e parlamentaristas.

Em relação ao termo utilizado para definir a diplomacia presidencial (coluna 6) notamos que alguns autores utilizam mais de um, de acordo com a ênfase que queiram dar a um aspecto específico da diplomacia presidencial. Assim, quando o interesse era enfatizar seu aspecto diplomático: ação diplomática (Danese, 1994), fenômeno diplomático (Cerqueira), instrumento diplomático (Ayllón), nova forma de diplomacia (Rojas \& Milet). Quando a ênfase era o seu aspecto político: fenômeno político (Ayllón). Já quando se queria abordar todos os seus aspectos: instrumento político-diplomático (Danese, 1999), ação político-diplomática (Ayllón). Outros autores utilizaram um só termo para se referir a ela em toda publicação: recurso de negociação (Malamud) e processo (Nuñez).

Danese (1999:21) abordou a diplomacia presidencial a partir de seus dois pilares básicos de sustentação: como instrumento particular de promoção de interesses do Brasil no exterior e como fenômeno político "que obedece a uma intensa lógica extra-diplomática, ligada ao papel e ao projeto político do presidente". Por isso o autor a identifica como "instrumento político-diplomático" e não somente político ou diplomático.

Em relação às características principais que definem a diplomacia presidencial (coluna 7), na maioria das vezes elas foram apreendidas no decorrer da publicação, ou seja, poucos autores as descreveram didaticamente, fazendo-o indiretamente.

Desse modo, a característica principal da diplomacia presidencial para Nuñez reside no fato do presidente propor temas novos as suas administrações diplomáticas. Antes da diplomacia presidencial esses temas eram traçados pela própria corporação diplomática para então serem passados ao presidente.

Já para Danese o que define essencialmente a diplomacia presidencial é o planejamento da política externa pelo presidente e a condução pessoal e ativa 
da mesma. Através da coluna 8 (característica oposta que define o conceito) pode-se observar que Danese concorda com Nuñez, visto que também considerou como chave para a definição do conceito a sua característica oposta, que é a diplomacia tradicional.

Rojas \& Milet apontaram características mais gerais para o conceito, como "síntese da representação estatal" e "um dos principais elementos da política externa" atualmente.

Para Malamud a diplomacia presidencial é um recurso que permite uma negociação direta entre presidentes, especificamente em resolução de crises. O autor analisou a diplomacia presidencial em 3 casos sensíveis do Mercosul. Ou seja, para esse autor, nos momentos de crise a diplomacia presidencial funciona como um recurso para os presidentes negociarem essa crise.

Para Ayllón, a diplomacia presidencial representa uma característica das Relações Internacionais na atualidade, assim como para Rojas \& Milet. Além disso, a principal característica do conceito é que ele está vinculado ao projeto político do presidente. Ou seja, há uma relação entre o projeto político interno do presidente e o seu projeto diplomático. Com isso, uma viagem presidencial reflete o interesse pessoal do líder e, ao mesmo tempo, o projeto diplomático do país.

Por fim, para Cerqueira, a diplomacia presidencial é uma estratégia, uma ferramenta para a inserção internacional do Brasil. Ou seja, é mais um instrumento diplomático a disposição do presidente para planejar e conduzir a política externa do país.

Todos esses itens estão interligados e só foram separados para fins de entendimento. Assim, a interpretação de quem é o ator (coluna 9) que realiza diplomacia presidencial depende de qual termo o autor utilizou para se referir à diplomacia presidencial (coluna 5): sendo diplomacia de cúpula, o ator será 0 chefe de estado ou de governo, sendo diplomacia presidencial será o presidente da República. Já em relação ao item onde e como a diplomacia 
presidencial se realiza (coluna 10) notamos que independe desse termo (independe da coluna 5).

Sobre o aspecto onde e como a diplomacia presidencial se realiza (coluna 10), observa-se que para Guilhon Albuquerque, Danese, Ayllón e Cerqueira, a diplomacia presidencial se produz em várias situações: encontros, pronunciamentos, atuações presidenciais em processos decisórios. Já para Nuñez ela é restrita a encontros presidenciais, assim como para Rojas \& Milet à reuniões de cúpula de chefes de estado e de governo. Para Malamud ela também é restrita a uma situação específica. Como o autor define a diplomacia presidencial como um recurso de negociação, ela se concretiza, por sua vez, em negociações que objetivam a resolução de uma crise ou em conflitos políticos.

O último aspecto da diplomacia presidencial analisado é se os autores estabeleceram ou não críticas a ela (coluna 11), seja no seu aspecto conceitual ou de prática político-diplomática. Observamos que Nuñez, Rojas \& Milet e Malamud não realizaram nenhuma crítica à diplomacia presidencial. Veremos os que o fizeram.

Para Danese a diplomacia presidencial é nos dias de hoje, um instrumento que complementa a diplomacia tradicional e muitas vezes é usado com exagero na execução da política externa e interna. Sua critica (1999:105-6) é sobre a banalização do uso da diplomacia de cúpula e sua perda de substância. Sua segunda crítica diz respeito ao forte conteúdo personalista dessa forma de diplomacia, muito dependente do perfil pessoal do presidente. Ou seja, é muito atrelada aos dotes pessoais e de personalidade do presidente, correndo o risco de ser identificada como algo passageiro, de uma gestão e não ligada a mecanismos institucionais.

Apesar dessas críticas, Danese aponta vários pontos positivos: a diplomacia presidencial recolocou o Brasil no mapa da diplomacia de cúpula mundial (1999:476) e a opinião pública hoje está mais preparada para compreender a diplomacia presidencial, desde que esta tenha uma mínima funcionalidade e 
desse modo possa neutralizar a visão de que ela compete com a boa administração e desvia a atenção do presidente dos problemas internos.

Para Guilhon Albuquerque, a "decantada 'diplomacia presidencial' " ainda não tem uma definição precisa e por isso ele é cético quanto à aplicabilidade desse conceito na realidade da política externa brasileira, acreditando que se atribui demasiada importância ao tema. A crítica do autor recai ao emprego generalizado do termo diplomacia presidencial, utilizado por muitos sem maiores reflexões.

Segundo Guilhon Albuquerque é comum considerar que quando o presidente viaja ao exterior ele automaticamente está fazendo uso do instrumento políticodiplomático que é a diplomacia presidencial. Para o autor isto não procede, pois, muitas vezes o presidente está seguindo instruções da corporação diplomática e não tem necessariamente autonomia nas decisões de política externa. Além disso, essas viagens podem ser simplesmente protocolares e não significarem nenhuma intervenção direta e autônoma do presidente em algum tema ou acordo internacional.

Danese, assim como Guilhon Albuquerque, faz ressalva quanto ao seu uso como sinônimo de 'viagens presidenciais' e, durante todo o seu livro (Danese, 1999), fornece indicadores para analisar se em uma dada situação houve diplomacia presidencial ou não. Apreende-se da obra de Danese que só é possível confirmar se um presidente fez uso da diplomacia presidencial com uma análise aprofundada da situação em questão.

Para Cerqueira a critica em relação à diplomacia presidencial está no uso que a burocracia diplomática fazia dela. Para o autor ela servia a vários interesses e objetivos, que mudavam com o tempo, além do que a sua definição era atrelada ao debate interno, ao qual o Itamaraty se dizia aberto. Cerqueira aponta que MRE tentava justificar a intensa agenda internacional de Cardoso com o intuito de fomentar o debate interno, porém, dentro dos parâmetros que garantissem apoio e legitimidade às suas próprias iniciativas. A diplomacia presidencial era o veículo para alcançar esse objetivo, pois se valia da 
cobertura da imprensa para transmitir internamente a boa receptividade que Cardoso tinha no exterior e reforçar na opinião pública e na sociedade as escolhas da chancelaria na arena internacional. Mas o autor mostra que nesse esforço o Itamaraty nem sempre foi bem sucedido, pois, ainda que o Itamaraty tenha mantido o controle sobre a formulação da política externa, o uso da diplomacia presidencial tornou público o debate sobre o processo.

Cerqueira aponta também críticas positivas à diplomacia presidencial, como 0 seu efeito de atrair a atenção da sociedade para assuntos relacionados à política externa, que ocorreu via cobertura da imprensa aos eventos que envolvem o presidente da República. O autor complementa que a diplomacia presidencial gerou um debate do qual participaram a chancelaria, a imprensa, analistas de política externa e outros formadores de opinião, permitindo assim que as funções e objetivos da diplomacia presidencial surgissem no debate doméstico.

Ayllón também expõe argumentos contrários à diplomacia presidencial. Para o autor a sua instrumentalização política como forma de legitimar internamente medidas de governo protegidas por sua aprovação no exterior é um aspecto negativo, somado ao excesso de viagens presidenciais e ao acentuado personalismo desta diplomacia, que confunde a esfera pessoal com os interesses nacionais.

Porém, o autor também atribui aspectos positivos à diplomacia presidencial: 0 seu uso como um poderoso instrumento de aproximação, fortalecimento e intensificação das relações entre países, que para ele representa a característica mais relevante na dinâmica recente das Relações Internacionais. Ayllón faz uma ressalva quanto a essa afirmação, que a diplomacia presidencial não é o único instrumento de que dispõem as burocracias.

Danese frisa que o elemento novo na diplomacia presidencial é a intensidade e generalização do seu uso, pois anteriormente a diplomacia era feita normalmente pelos chanceleres. 
Assim como Danese - e Guilhon Albuquerque também o fez - Nuñez destacou o aumento da intensidade do uso deste instrumento como um novo elemento da diplomacia presidencial atual, mas não de forma crítica. Ele afirma que no contexto da diplomacia presidencial se destacam a amplitude, a freqüência e a intimidade que há nestes encontros presidenciais. O autor considerou o fator "intimidade" nos encontros como um novo marco, que exemplifica com o relato de Fernando Henrique Cardoso, onde este comparou o tom cerimonioso que havia nas primeiras reuniões dos presidentes Alfonsín e Sarney, e que foi sendo substituído por um tratamento mais informal entre os presidentes e os ministros, que o autor qualificou de um tratamento mais fácil e franco (1997:135).

A discussão aqui apresentada, sobre a análise e comparação da literatura que abordou o tema diplomacia presidencial e a sua relação com a o conceito de diplomacia presidencial em si - objeto de estudo desse trabalho -, será realizada mais densamente nas considerações finais (alguns paralelos já foram traçados aqui).

No capítulo seguinte serão analisadas as teorias sobre a ação do presidente da República em política externa, estabelecendo um paralelo dessas com o conceito de diplomacia presidencial. 


\section{CAPÍTULO 3 - A AÇÃo dO PRESIDENTE dA REPÚBLICA NO ÂMBITO DE POLÍTICA EXTERNA}

Nesse capítulo se estudará as diferentes teorias sobre a ação do presidente em política externa, para poder situar o conceito de diplomacia presidencial nesse debate. Especificamente a mudança que tem ocorrido neste papel nos últimos anos, que alguns analistas intitularam diplomacia presidencial.

As teorias que se dedicam ao estudo de política externa são conhecidas como análise de política externa ou Foreign Policy Analysis (FPA) em inglês. São uma sub-área das relações internacionais ${ }^{35}$ e surgiram no final dos anos 50 como uma abordagem crítica ao Realismo, que considera o Estado como ator unitário, racional e com preferências já pré-definidas a respeito do comportamento internacional. Esse novo paradigma procurava elementos de explicação da formulação de política externa tanto dentro quanto fora do Estado. Dentre essa literatura há uma vertente que inicialmente se concentrou nos estudos sobre os processos decisórios e posteriormente numa análise dos mecanismos de cognição e percepção dos policy-makers (Mello e Silva, 1998:142). O objetivo dessas teorias é analisar o processo de tomada de decisão em assuntos de política externa: como as decisões são tomadas, quais os atores envolvidos, como se forma a agenda, etc.

A teoria de análise de política externa estabelece uma relação entre o sistema internacional e o sistema doméstico, com objetivo de identificar como as variáveis domésticas influenciam o comportamento do Estado na política externa.

O campo de análise de política externa é dividido em três modelos (Onuki, 2002:16):

1) analisa os efeitos da política doméstica no comportamento internacional do país. Allison e Hermann são exemplos do que se denomina "primeira geração da foreign policy analysis". Como aponta Pinheiro (2000), a partir de meados

\footnotetext{
35 “... diversos analistas rotulam a análise de política externa não como uma subdisciplina de relações internacionais, mas sob o ramo da ciência política de políticas públicas” (Altemani, 2005:22).
} 
dos anos 70 , essa vertente da foreign policy analysis surgiu no exterior e ganhou força no Brasil devido a mudanças de regimes autoritários para democráticos, o que incitou novos instrumentos de análise da realidade política do país.

2) análise cognitiva de política externa. Aqui se destaca os estudos sobre o papel da liderança e da percepção política dos policy makers; como o trabalho de George e Margareth Hermann (1988). Podemos afirmar que os trabalhos sobre diplomacia presidencial no Brasil se encaixam nessa vertente.

3) política externa comparada. Segundo Onuki, nesse modelo se torna mais difícil a análise, pois exige que os elementos a serem comparados estejam definidos de modo muito claro.

Rosenau descreve a FPA como uma bridging discipline (1987:1), pois ela tem como foco o estudo de assuntos que estão interligados entre si, como o estado-nação, que é interligado ao sistema internacional. Ele complementa que a disciplina procura organizar pesquisas sobre o comportamento exterior dos estados-nação, ou seja, a política externa dos governos. Assim, um meio de estudar esse campo sem fronteiras, como ele nomeou a FPA, é ponderar sobre os vários significados e explicações que se pode fazer numa simples ação de política externa. O exemplo que ele utiliza é o de uma viagem do chefe de estado. Esse evento reflete ao mesmo tempo uma decisão de um indivíduo, as deliberações do comitê, o outcome do processo de policy-making, a soma de grupos de interesse contrários, os valores da elite dominante, o produto das aspirações sociais, o reforço da tradição histórica, a resposta a uma oportunidade ou desafio de algum lugar no mundo. E esse elenco, segundo o autor, somente se refere a algumas explicações que os estudantes de política externa poderiam apontar no estudo desse ato de política externa.

No Brasil análises com essa perspectiva são raras. Essa bibliografia ainda está se formando no nosso país e dentro dela nem todos os estudos se dedicaram a estudar especificamente o papel do presidente da República.

Pinheiro (2000:451-2) observou que em meados da década de 70 , tanto no Brasil, quanto no exterior, surgiram estudos voltados para determinantes 
domésticos da política externa. Mas que no tocante ao processo decisório, as pesquisas no Brasil continuavam muito tímidas ${ }^{36}$. A autora aponta três variáveis para isso:

- crença num consenso entre as principais forças políticas e econômicas sobre orientações gerais de política externa;

- papel aparentemente hegemônico do Itamaraty, o que resultou em uma maioria de análises que alegavam a autonomia do MRE, "... o que os liberava de uma investigação mais criteriosa sobre outros atores participantes do processo";

- a impossibilidade de acesso a fontes privilegiadas de pesquisa.

Dos anos 70 até hoje temos 3 décadas, mas essa literatura pouco avançou no Brasil.

Nesse capítulo procurou-se destacar alguns trabalhos que na bibliografia internacional analisaram a ação do presidente em política externa. A seleção teve o objetivo de abordar trabalhos que exemplifiquem as orientações da literatura internacional existente sobre o assunto, que é vasta. Posteriormente, se situará a categoria diplomacia presidencial nessa discussão.

O capítulo se inicia com a obra de Allison (1969), que é uma das teorias mais citadas sobre a abordagem de decisões em política externa. A escolha pela análise da sua obra se justifica por ser ele um dos primeiros autores a propor uma abordagem de política externa como política pública, onde se reconhece conflito de interesses e vários grupos atuando, o que se contrapõe as abordagens da política externa enquanto política de estado.

A seguir, M e C. Hermann (1989) tem outro importante trabalho, onde analisam como os decision-makers tomam suas decisões, elaborando uma classificação de tipos de decisores. Esse trabalho dos Hermann é outro exemplo da primeira

\footnotetext{
${ }^{36}$ Isso não quer dizer que não havia pesquisas sobre o processo decisório de política externa brasileira no período, inclusive ela indica alguns trabalhos (2000:452). Nesses trabalhos, apesar das divergências, as visões mais recorrentes sobre quem seria a unidade de decisão final atribuiu esse papel ao presidente da república, ao Conselho de Segurança Nacional e ao Itamaraty em especial.
} 
geração da foreign policy analysis, que estabelece explicações com base em modelos $^{37}$.

Já Alexandre George (1988) analisou modelos e estilo de gerenciamento dos presidentes no que concerne à política externa. Ele é um representante da análise cognitiva de análise de política externa e exemplifica as abordagens que demonstram a influência de características pessoais na tomada de decisões $^{38}$.

E por fim, tem-se a categoria de homem de estado de Duroselle, que é um clássico dentre a perspectiva européia.

\subsection{DifERENTES ABORDAGENS TEÓRICAS}

Allison em seu artigo de 1969 "Conceptual models and the cuban missile crisis" analisou o bloqueio americano a Cuba, que aconteceu em outubro de 1962 e durou 13 dias. A escolha desse evento como estudo de caso, deveu-se a sua importância. Nas próprias palavras do autor, nesse evento "houve uma alta probabilidade que mais vidas humanas acabassem de repente, do que nunca antes visto na história (Allison, 1969:689)".

O autor elaborou 3 modelos conceituais que explicam porque foi escolhida a decisão de bloqueio perante outras alternativas. Esses 3 modelos conceituais irão explicar, cada um utilizando categorias diferentes, como se deu a tomada de decisão para um mesmo evento (o modelo é aplicado ao evento para produzir uma explicação). Cada caso é explicado como um exercício de gerar hipótese e não de testar hipóteses e a conclusão mostra que os 3 modelos podem gerar predições.

\footnotetext{
${ }^{37}$ Holsti (1989), assim como Allison e Hermann, descreveu três modelos de tomada de decisão. Nesse sentido o seu trabalho é semelhante ao de Allison e ao de Hermann, pois também trabalha com elaboração de modelos explicativos, baseados na interpretação da literatura já existente.

${ }^{38}$ Um outro exemplo muito conhecido dessa abordagem é Hermann, Margareth G. (1988).
} 
Para Tomassini (1989:234), na verdade a construção dos modelos é mais importante do que a análise da crise em si, pois o propósito inicial de Allison foi sintetizar as idéias principais de três correntes da literatura. Ele o fez via o desenvolvimento desses três modelos conceituais, que foram construídos para explicar como os analistas internacionais pensam os problemas de política externa.

Segundo Allison, analistas pensam sobre problemas de política externa e militar em termos de modelos conceituais implícitos que tem conseqüências para o conteúdo do seu pensamento. Ao explicar um evento, o analista deixa implícito quais categorias utilizou, as evidências que considerou relevantes, os determinantes das ocorrências (não se desenvolve todo o evento) e seus pressupostos. Para o autor esses pressupostos funcionaram como um quadro de referência, um modelo conceitual, no qual as análises estão baseadas e a partir do qual o analista pode propor questões e respostas a respeito do evento ocorrido. Esses pressupostos são centrais tanto para a atividade de explicação, quanto para a de predição.

Para ele, a maioria dos analistas explica (e prediz) o comportamento dos governos nacionais em termos de formas variadas do modelo 1 , que é 0 modelo conceitual básico, intitulado modelo de política racional. Os outros dois modelos conceituais são os alternativos.

Para o modelo 1 as ações de política externa são as escolhas, para o 2 são 0 produto (de grandes organizações funcionando segundo padrão regular de comportamento) e para o modelo 3 são um resultado, uma conseqüência da barganha entre vários jogadores do governo nacional, organizados hierarquicamente e que possuem percepções, motivações, posições, poder e manobra.

Modelo 1: política racional

A maioria dos analistas contemporâneos utiliza esse modelo conceitual para explicar os acontecimentos de política externa. Eventos de política externa são ações, analisadas racionalmente por um governo nacional, que seleciona a 
ação que irá maximizar suas metas e objetivos. É a resposta calculada para um problema estratégico que a nação enfrenta. Nesse modelo a nação ou governo nacional é concebido como o decision-maker unitário racional. Ele então tem um conjunto de metas e objetivos e um conjunto de opções para realizá-los e faz uma estimativa das conseqüências percebidas para cada ação. Segundo esse modelo, a explicação para os posicionamentos dos mísseis soviéticos em Cuba foi motivada pelo desejo da liderança soviética alcançar a ampla margem de superioridade estratégica dos EUA. E do ponto de vista americano o bloqueio a Cuba foi a alternativa maximizadora.

\section{Modelo 2: Processo Organizacional}

Nesse modelo o comportamento do governo - concebido como um conglomerado semi-feudal de organizações - em política externa não é uma escolha deliberativa de um líder e sim o produto da interação de diversas organizações, que são coordenadas parcialmente pelos dirigentes governamentais. Tais dirigentes podem interferir na conduta dessas organizações, mas não as controlam, já que esse comportamento organizacional é determinado previamente por procedimentos já estabelecidos. Os atores desse modelo não são uma nação ou governo monolítico, mas um conjunto de organizações, no qual os seus membros são somente componentes e os líderes governamentais se encontram no topo, coordenando as rotinas desempenhadas por esses membros.

Os presidentes raramente tomam decisões, pois as suas opções para a solução de um problema de política externa fazem parte das rotinas organizacionais já existentes. Portanto, há uma distância entre o que os líderes escolhem e o que as organizações implementam.

Como o funcionamento do governo é similar ao de uma organização, os problemas são divididos dentro de cada departamento da organização, e com isso, cada parte percebe um pedaço do problema, processa informação e desempenha um rol de ações - descentralização da responsabilidade e do poder -, o que permite uma atenção mais especializada do que se líderes enfrentassem os problemas sozinhos. 
Assim, a crise dos mísseis é explicada por um número de fatores organizacionais e não pela superioridade ou inferioridade militar dos EUA. Se ocorresse, seria o resultado da atividade das organizações. Em 14 de outubro de 1962 os EUA descobriram a presença de mísseis em Cuba e essa descoberta é uma conseqüência de rotinas estabelecidas e procedimentos organizacionais, sendo que o que determinou a escolha pelo bloqueio foi exatamente essa descoberta.

Modelo 3: Política burocrática

Para esse modelo de comportamento, a ação do governo não é um produto das organizações, mas o resultado de um jogo de barganha entre indivíduos e grupos no governo. Aqui os líderes que se sentam no topo das organizações não são um grupo monolítico - como também não o eram para o modelo 2 - ou seja, não há um ator unitário, mas cada um é um jogador importante e competitivo no jogo de política externa. Esses atores individuais não se concentram num só assunto estratégico, mas em vários problemas nacionais, já que há uma convivência de interesses distintos. Apesar de haver um compartilhamento de poder por indivíduos com responsabilidades separaras, os atores podem diferir no que será feito.

O que faz com que um curso de ação seja escolhido é o poder e a habilidade dos proponentes e componentes da ação em questão e não a razão (modelo 1) ou rotinas organizacionais (modelo 2 ).

Essa habilidade do jogador depende de seu poder (influência efetiva em resultados políticos, percepção do outro jogador, expertise, status, etc.), mas só poder não é suficiente para resultados estratégicos, ele necessita também de outros jogadores (muitos assuntos, vários jogos faz lutar pela atenção do outro).

Os resultados não são uma solução escolhida para um problema, mas uma barganha entre os jogadores, cada qual com objetivos diferentes. Os jogadores são pessoas ou organizações, cada um com um estilo de gerenciamento e 
personalidade, com uma bagagem - incluindo sensibilidade para certos assuntos, reputação pessoal, debate com grupos da sociedade -; com interesses variados e distintos, com uma concepção de interesse nacional. Assim, a ação raramente foi à exata intenção de alguém, já que são vários indivíduos com várias e diferentes intenções. $O$ que a nação faz às vezes é resultado do triunfo de um grupo sob o outro.

A explicação do descobrimento dos mísseis, que é a explicação para o bloqueio, deve-se a poderosa coalizão de conselheiros, de pessoas de grande confiança e com estilo compatível ao do presidente.

O autor conclui que os 3 modelos são alternativas não excludentes, apenas cada um deu ênfase a um aspecto diferente do quadro e abandonou o outro. Nos modelos 2 e 3 o comportamento do governo é um fator relevante, mas não o único. Os paradigmas expostos por Allison fornecem uma base para um reexame sério de muitos problemas de política externa e militar; os modelo $2 \mathrm{e}$ 3 fazem avanços importantes na explicação e predição comparados ao modelo 1, e apesar desses 2 modelos requererem grandes somas de informação, que por vezes não estão disponíveis, mesmo com informação limitada avanços são possíveis e eles podem ser sugestivos.

Além disso, a importância do artigo, como o próprio autor aponta, está em mostrar quadros de alternativas de diferentes análises, que podem ser explorados por estudantes e pesquisadores.

O modelo 3 de Allison se aproxima da diplomacia presidencial no que concerne à abordagem da política externa como política pública. Para a abordagem da diplomacia presidencial a política externa funciona como uma política de governo, uma política pública, com suas mudanças e incorporação de grupos heterogêneos no processo decisório de assuntos exteriores, assim como para o modelo de política burocrática. 
Em seu artigo "Who makes foreing policy decisions and how: an empirical inquiry" (1989) Margaret e Charles Hermann desenvolveram o conceito de unidade de decisão final para analisar quem toma as decisões em assuntos exteriores e qual o efeito dessa unidade no comportamento da política externa.

Os autores fizeram um balanço da literatura de política externa e concluíram que muitos analistas têm focado em organizações burocráticas para explicá-la, outros focaram no papel de pequenos grupos e outros ainda examinaram as qualidades dos líderes. A maioria desses trabalhos considera essas três configurações separadamente, sem questionar porque determinada unidade ao invés de outra se sobressai, e quais conseqüências disso para o comportamento de política externa. M. e C. Hermann consideraram as três abordagens como relevantes para e propuseram um modelo que determina qual unidade de decisão está atuando num problema específico de política exterior, mas como o interesse na obra dos autores não é a metodologia que utilizaram para identificar a unidade de decisão final, ela não será detalhada aqui. $^{39}$

Os autores classificam a unidade de decisão final em 3 tipos, sendo que o tipo líder predominante é o que interessa para essa pesquisa, pois se aproxima da

\footnotetext{
${ }^{39}$ Para determinar qual é a unidade de decisão final num determinado governo e em relação a um problema específico de política externa os autores primeiramente desenvolveram 4 pressupostos:

1- A unidade de decisão final pode variar segundo o problema de política externa, embora em alguns países quase não haja variação;

2- unidades de decisão com o poder para tomar uma decisão, nem sempre escolhem fazê-lo;

3- certos tipos de problema aumentam a probabilidade de unidades particulares exercerem a autoridade última;

4- a identificação da unidade de decisão final para um problema específico é quase sempre uma tarefa inferencial, na qual o analista exclue possibilidades e encontra evidências com as quais estima a unidade provável.

Pois bem, baseados nesses 4 pressupostos, os autores desenvolveram um organograma com questões (Hermann, 1989: 370-1, fig.1), primeiro identifica-se o problema de política externa, depois se faz perguntas, como: se há um grupo com capacidade para comprometer os recursos e se há um líder nesse grupo, se esse líder inclui outros nas decisões, etc., visam descobrir qual é a unidade de decisão final. Os autores coletaram dados sobre as unidades de decisão em 25 países entre 1959 e 1968 para estimar o provável tipo de unidade de decisão final que predominou para um número de problemas de política externa que esses países enfrentaram nessas décadas (tabela 2- p.374-375).

Para essa classificação ser útil em fornecer informações sobre o comportamento de política externa de um país para um dado problema, os autores desenvolveram, para cada tipo de unidade de decisão final, variáveis de controle chave. Elas são uma peça chave de informação sobre que elementos devem ser considerados no cálculo de cada unidade, se somente focam na própria unidade ou se em fatores fora desta. Assim, a variável de controle para o líder predominante é a sensibilidade ao contexto, para o grupo individual é o consenso imediato, para os múltiplos atores anônimos é o relacionamento entre os atores. Se a unidade for sensível ou insensível em relação a essa variável, será classificada em auto contida ou externamente influenciável.

Além de identificar qual a unidade de decisão final e elaborar as 3 variáveis de controle chave, eles desenvolveram medidas de extremo e moderado comportamento de política externa, baseadas em cálculos numéricos.
} 
categoria diplomacia presidencial, portanto, será melhor detalhado mais à frente.

Segundo eles (362-3), unidade de decisão final são indivíduos, grupo de indivíduos ou atores múltiplos que, dentro de um governo que identificam, decidem e implementam a política externa. São os decision-makers; mas não qualquer decisor, mas somente aqueles que possuam duas características específicas: a habilidade de comprometer os recursos do governo em assuntos externos e o poder ou autoridade para prevenir outras entidades do governo de reverter sua posição, sem custos significativos. Assim, em uma questão pode haver vários atores com capacidade de decisão, vários decisores, mas somente um será a unidade de decisão final (seja ele uma pessoa ou um grupo).

M. e C. Hermann esclarecem que há hoje em dia inúmeros atores no processo decisório de política externa, tanto governamentais, seja do Executivo ou do Legislativo $^{40}$, quanto fora do governo. Porém, esclarecem eles, para a maioria dos problemas de política externa alguém toma uma decisão que não pode ser facilmente revertida. Esse, e somente esse ator (ou conjunto de atores), consiste na unidade de decisão final para aquele assunto e naquele momento específico.

A unidade de decisão final varia segundo a natureza do problema de política externa e segundo o tempo particular em que o evento ocorre. Há, no entanto, países em que ela não varia muito. Apesar disso, para assuntos de vital importância para a nação é provável que as mais altas autoridades políticas sejam a unidade de decisão final. Já para problemas de rotina, ela pode se situar no nível mais baixo da hierarquia governamental. Nesse caso provavelmente haverá uma unidade mais alta na hierarquia capaz de reverte a sua decisão. Assim, conclui-se que certos tipos de problema aumentam a probabilidade de unidades particulares exercerem a autoridade final. Porém, mesmo que a estrutura da unidade de decisão final varie, é ela que formará a

40 Eles citam como possíveis unidades de decisão final: os primeiros ministros, os presidentes, os politburos, as juntas, os ministérios, os grupos inter-agência, as coalizões e os parlamentares (1989: 361). 
política externa do governo, por isso os autores frisaram que essa categoria é central para a compreensão do foreing-policy process.

Há três tipos de unidade de decisão final, os dois primeiros são:

1) Grupo de indivíduos: quando um conjunto de indivíduos pertencentes a um mesmo grupo seleciona coletivamente uma linha de ação, que é capaz de obter total concordância entre seus membros;

2) Múltiplos atores autônomos: quando um conjunto de indivíduos, grupos ou facções, com existência relativamente autônoma, é incapaz de, separadamente, comprometer os recursos do Estado com objetivo de adotar uma linha de conduta.

E cada uma dessas unidades pode diferir segundo dois fatores: se a unidade de decisão final afeta a política externa através de seu conhecimento, crenças e estilo dos participantes na unidade (unidade auto-contida) ou se fatores de fora da unidade de decisão influenciam os resultados de política externa (unidade externamente influenciável), ou seja, segundo sua maior ou menor vulnerabilidade à influências externas41.

O terceiro tipo de unidade de decisão final, e o mais relevante para esse estudo é o:

3) líder predominante: quando uma pessoa sozinha tem o poder de fazer a escolha para o governo. Nesse tipo de unidade de decisão é importante conhecer as características pessoais do líder predominante, pois as orientações políticas dele indicarão quão sensível ele será a conselhos e influências do ambiente externo ao tomar uma decisão em política externa. Já o conhecimento sobre a orientação desse líder em assuntos externos, seu conjunto de visões sobre como o governo deve agir na arena exterior, é importante para explicar a reação dele a um problema particular de política externa.

\footnotetext{
41 Pinheiro (2000:456) descreve as unidades de decisão final e as aplica ao processo decisório de política externa no regime militar brasileiro.
} 
Quando a unidade de decisão final é o líder predominante, a questão que se coloca é se a orientação dele para assuntos externos o torna relativamente sensível ou insensível à informação do meio ambiente político. Se o líder é relativamente insensível, o conhecimento sobre a personalidade dele pode sugerir, via o seu comportamento na política externa de seu governo, o que ele é apto a fazer. O líder predominante insensível é uma unidade de decisão autocontida. Já quando o líder é sensível, necessita-se entender outros aspectos do sistema político vigente para sugerir o que o governo fará em resposta a um problema de política externa - dados de personalidade não serão suficientes. O líder predominante sensível é uma unidade de decisão final externamente influenciável.

Os autores concluem que as pressões internas e externas podem predispor um governo a agir de modo particular, mas o caráter preciso dessas ações irá ser modificado pelas propriedades da unidade de decisão final; portanto, torna-se importante averiguar qual o tipo de unidade de decisão final para um problema específico.

Quando o decisor de um problema específico de política externa num dado momento é o líder predominante, isso quer dizer que ele foi a autoridade máxima de política externa naquele momento, mesmo que outros atores tenham participado do processo. Essa caracterização independe do líder ser sensível ou insensível às opiniões e ao ambiente externo. O líder predominante pode ser o presidente da República. Numa análise de um estudo de caso de política externa, será necessário levar em conta suas característica pessoais (se insensível) e/ou o contexto (se sensível). Essa categoria se aproxima da categoria de diplomacia presidencial, uma vez que essa última se refere ao presidente enquanto autoridade máxima e autônoma de política externa, mas, ela está muito mais elaborada em $\mathrm{M} \mathrm{e} \mathrm{C}$. Hermann, uma vez que os autores detalharam ${ }^{42}$ como fazer para se identificar se o líder predominante é a unidade de decisão final, enquanto que a literatura que trata da diplomacia presidencial não é clara sobre como identificar quando o presidente da República exerceu

\footnotetext{
${ }^{42}$ Conferir nota 38 , sobre a metodologia de pesquisa empregada pelos autores.
} 
ou não a decisão final, já que ainda não se tem um trabalho detalhado sobre esse aspecto.

Alexander L. George, em seu artigo "The president and the management of foreing policy: styles and models" (1988), descreveu três diferentes abordagens do papel dos presidentes no gerenciamento das tarefas de mobilizar informação disponível, expertise e recursos analíticos para efetivo policymaking. Os três modelos recebem os nomes: formalista, competitivo e colegiado. Lembremos que aqui, o autor se refere sempre à política externa dos EUA.

Para o autor, todo novo presidente enfrenta no seu governo a tarefa de decidir como estruturar e gerenciar o alto nível de política externa. Como a responsabilidade de política externa nos EUA é dividida em inúmeros departamentos e agências, a informação relevante, a competência, a influência sobre a política estão dispersas pelo Executivo e fora dele. Isso impõe ao presidente e seus assistentes à tarefa de mobilizar informação disponível, expertise e recursos analíticos para um efetivo policy-making.

Assim, a primeira tarefa de um novo presidente é definir o seu próprio papel no sistema de formulação de política externa, para, após isso, poder estruturar e gerenciar o papel dos outros envolvidos nesse sistema e suas relações, como do secretário de estado, secretário de defesa, o assistente especial para assuntos de segurança nacional e outros líderes de agência e ministérios com responsabilidade de formular e implementar política externa. Isso implica em decidir se ele presidente dará o papel principal em assuntos de política externa ao secretário de estado ou se centralizará e gerenciará da Casa Branca esses assuntos, ou seja, o sistema de policy-making, ou ainda se optará por um sistema relativamente descentralizado, que seria coordenado da Casa Branca por ele e seu assistente especial de assuntos de segurança nacional.

O presidente pode receber conselhos de especialista de política externa, mas suas escolhas em decisões de política externa são em última análise formadas por: suas próprias preferências, que podem ter origem em experiências 
anteriores no Executivo; pelo grau em que ele se julga conhecedor e competente em questões de política externa e segurança nacional; e por sua personalidade. Assim, cada presidente pode desenvolver um sistema de policymaking e um estilo de gerenciamento distinto. Analisando os antigos presidentes, George observou várias características pessoais importantes, que influenciaram a escolha do presidente no processo de policy-making e na sua seleção do modelo do mesmo, então ele destacou 3 delas.

A primeira é o "estilo cognitivo", que se refere ao meio no qual o presidente define a necessidade de informação que precisa para tomar uma decisão de política externa e se refere também aos meios preferidos do presidente de obter informações e fazer uso delas, e de considerar as informações de seus conselheiros e os meios de usá-las na tomada de decisão.

A segunda característica de personalidade é seu "senso de eficácia e competência" para o gerenciamento e tomada de decisão, ou seja, as habilidades que o presidente possui e os tipos de tarefa que ele se considera hábil ou não para fazer, que irão influenciar o modo como ele define seu papel no Executivo.

A terceira é sua "orientação geral em relação ao conflito político" e em relação ao conflito político entre seus conselheiros. George salienta que alguns presidentes vêem a Política como uma necessidade, útil e até um jogo agradável, enquanto outros presidentes a consideram um negócio sujo que deve ser desencorajado ou ignorado. A atitude do presidente em relação ao conflito determinará sua orientação para a política de ministérios e para a política burocrática dentro do Executivo. Assim, o presidente com tendência a evitar conflitos, preferirá um staff e conselheiros onde a equipe de trabalho ou procedimentos de análise formais são valorizados ao invés do debate.

George conclui, portanto, que o estilo cognitivo, senso de eficácia e orientação sobre o conflito, somados com as experiências anteriores do presidente em papéis do Executivo e o nível de competência pessoal e interesse em política externa e assuntos de segurança nacional, todos esses elementos combinados 
determinarão como um novo presidente estruturará o sistema de policy-making e definirá seu papel e dos outros nesse sistema.

A análise da ação presidencial nas experiências recentes identificou três modelos de gerenciamento: o formalista, o comportamental e o colegiado.

O modelo formalista é caracterizado por uma ordenada estrutura de policymaking, que fornece procedimentos bem definidos, linhas hierárquicas de comunicação e um sistema de staff estruturado. Esse modelo desencoraja o conflito aberto e a barganha.

O modelo competitivo, ao contrário do anterior, encoraja uma maior diversidade de opiniões, de análises e de conselhos. Para tal, esse modelo não só tolera, mas também encoraja a ambigüidade organizacional, maior cobertura de jurisdição e múltiplos canais de comunicação em relação ao presidente.

O modelo colegiado busca as vantagens essenciais de cada um dos dois anteriores enquanto evita suas fraquezas. Nele o presidente cria um time de membros do staff e conselheiros que trabalharão juntos para identificar, analisar e solucionar problemas políticos. Esse modelo encoraja a participação colegiada - de modo que pontos de vista divergentes sejam incorporados; mas também os encoraja a se identificarem, ao menos parcialmente, com a perspectiva presidencial. Essa abordagem tenta evitar os excessos de briga, a barganha e concessões dentro do time, relacionados ao modelo competitivo.

George analisa brevemente (1988:110-125) alguns governos dos EUA, como F. Roosevelt, Truman, Eisenhouer, Kennedy, Nixon, e os classifica em um dos 3 modelos, segundo suas principais características pessoais. Assim, Trumann, Eisenhouer e Nixon utilizaram variantes do formalista; Roosevelt do competitivo e Kennedy do colegiado.

Enquanto M. e C. Hermann analisam o papel do presidente observando suas relações no interior do sistema de política externa, George se atem principalmente às características pessoais do líder. Estas são para esse autor, 
a variável que determina as relações no sistema de formulação de política externa. Essa abordagem se aproxima da categoria de diplomacia presidencial na medida em que tenta entender e descrever como age o presidente em decisões de política externa, porque um presidente é mais centralizador que outro, mais aberto à opinião que outro, etc. A classificação de modelos de George se aproxima mais da categoria de líder dominante de M. e C. Hermann do que da categoria de diplomacia presidencial, pois, uma vez mais, aqui em George ela está cuidadosamente descrita e foi empiricamente testada, diferentemente do que ocorreu com o conceito da diplomacia presidencial.

O livro Introdução à História das Relações Internacionais, de 1965, escrito pelos historiadores franceses Pierre Renouvin e Jean-Baptiste Duroselle, tem sua segunda parte, escrita por este último, dedicada à análise do homem de estado.

Os autores tentam compreender como as forças profundas influenciam as Relações Internacionais e qual o papel que desempenharam a personalidade e as idéias do homem de estado em certas ocasiões; qual a sua concepção de interesse nacional; como seu caráter e seu temperamento podem influenciar sua política; em que condições ele toma as decisões. Além disso, estuda como as forças profundas influenciam esse homem e como ele tenta modificá-las. Cabe ressaltar que é um estudo histórico das Relações Internacionais.

Para os autores, as relações internacionais são pensadas a partir de duas categorias: as forças profundas e os homens de estado e são entendidas como o resultado da relação entre ambas:

"Renouvin parte de la consideración de las influencias que orientan el curso de la acción diplomática y su impacto en la voluntad del gobernante. A estas influencias lãs denomina "fuerzas". Como señala DUROSELLE, todo acontecimiento político - es el caso de las relaciones internacionales - se sitúa en el punto de unión de un sistema de finalidad y de un sistema de causalidad. A la finalidad, es decir, al estudio de la estrategia y de las decisiones, Renouvin la denomina "el papel del hombre de Estado". Las actuaciones de éste - la finalidad - se encuentran condicionadas por una serie de constreñimientos de carácter físico (geográficos), demográficos, económicos, ideológicos, etc. que se 
le sobreponen: la causalidad. Estos constreñimientos son lãs fuerzas profundas, materiales y morales..." (Ayllón, 2004:53)

Assim, podemos definir de modo genérico o papel do homem de estado como o conjunto de estratégias e de decisões que ele toma com uma finalidade específica de política externa. Às forças profundas podemos identificar os constrangimentos que condicionam a atuação do homem de estado. Eles consistem nas condições geográficas, movimentos demográficos, interesses econômicos e financeiros e traços da mentalidade coletiva.

Do mesmo modo como as forças profundas podem mudar os acontecimentos históricos, a vontade do homem de estado também pode fazê-lo. Com isso Duroselle analisou a ação das forças profundas - de caráter econômico ou ideológico - sobre o homem de estado e conclui que assim como a sociedade imprime sua marca em todo indivíduo, ela também exerce influência sobre o homem de estado. Porém, ele pode modificar a conjuntura, tendo consciência que as forças profundas existem e procurando utilizá-las, o homem de estado não se enfraquece, mas tem a possibilidade de aumentar o seu poderio. Um exemplo são as potências que possuem armas nucleares. O seu uso depende de um simples ato do homem de estado. Opinião pública e forças econômicas, são motores que impulsionam o homem de estado, mas também são realidades maleáveis, ou seja, o homem de estado pode tentar modificá-las.

Segundo Dureselle (1965:301), uma vez resolvido o problema das forças que atuaram sobre o homem de estado, certos aspectos das decisões se explicam pelo "temperamento" do responsável. Nessas condições procurar-se-á conhecer melhor esse temperamento pelo estudo de textos, de testemunhos, do comportamento.

Querendo saber como as atitudes históricas podem ser explicadas pela personalidade, o autor se pergunta quais são, sob o ponto de vista histórico, os grandes traços característicos que importam conhecer nos atores. O método foi o exame de documentos, dos discursos, dos problemas que os homens de estado ou embaixadores enfrentam perante outros iguais, estrangeiros. Desse 
modo o autor desenvolve uma tipologia dos homens de estado, segundo suas principais características.

Uma categoria que sempre permeia as discussões de política externa e que Duroselle analisou é o interesse nacional. Para o autor ela corresponde a crença "verdadeiramente confusa" de que, em dada situação, se pode determinar objetivamente os alvos - distantes ou próximos - que a nação deve visar. Essa categoria ganhou vigor (em oposição ao interesse do príncipe) com o desenvolvimento da instituição democrática. Mas para os estadistas, que selecionam os possíveis objetivos de sua política externa, o interesse nacional é, conscientemente ou inconscientemente, o resultado de suas seleções. Segundo o autor, é difícil uma nação ter um interesse nacional objetivo, já que a sociedade está dividida em classes e em grupos de interesse, que em geral têm aspirações contraditórias.

O autor frisa que, em matéria de interesse nacional, política doméstica e política externa se confundem. Vê-se isso quando uma pressão ligada à política doméstica obriga o homem de estado a tomar uma iniciativa externa diferente da planejada. Observa-se também o uso da política exterior para desviar a atenção de problemas internos (alguns estadistas ganharam as eleições porque ganharam a guerra).

Assim, o fato das políticas interna e externa se misturarem, faz com que seja difícil identificar se uma decisão de política externa teve um objetivo doméstico ou exterior. Além disso, quando o homem de estado se propõe um objetivo, ele pode considerar esse objetivo um fim em si ou um meio para se alcançar um objetivo distinto. Em raros casos pode-se separar essas duas ações. Desse modo, para Duroselle, é difícil identificarmos o objetivo de uma ação de política externa, seja ele o interesse nacional ou não.

Em seu livro, o capítulo 13 é dedicado ao estudo das decisões. Duroselle aponta que a decisão é a atividade mais alta do homem político, a que the justifica as funções. Ainda que gaste essa parte do seu tempo acolhendo 
visitantes, recebendo opiniões e relatórios de seus subordinados, estudando documentos, fazendo discursos e desempenhando um papel de representação.

O autor descreve as fases de trabalho referentes ao estudo do historiador sobre a tomada de decisão. Este ocorre em 2 fases: a primeira fase de trabalho - o estabelecimento dos fatos - pressupõe entender que decisões foram tomadas, quem as tomou e em que circunstâncias; a segunda consiste em explicar a decisão ou a seqüência de decisões.

Mas a resposta à questão "quem tomou a decisão" não é fácil. A estrutura jurídica permite identificar a autoridade responsável. Por exemplo, nos regimes parlamentares é o conselho de ministros e no regime presidencialista, é o presidente. Já numa ditadura pessoal, é o próprio ditador. Mas geralmente têmse poucos meios de se saber quem foi o responsável efetivo, a autoridade responsável pode delegar quase todos os seus poderes de política externa a um subordinado. Também, pelo menos nos regimes fracos, um subordinado pode tomar uma iniciativa.

O autor esclarece (1965:440-1) que toda decisão implica riscos e no cálculo do risco pode-se cometer erros. Quem geralmente decide se correrá ou não este risco é o homem de estado. Essa decisão pode depender de seu temperamento e de outros fatores, como, por exemplo, se o país está satisfeito ou insatisfeito. Um país satisfeito é menos disposto a arriscar que um insatisfeito. Um país pode ser insatisfeito territorialmente, isto é, o país que não tem unidade nacional ou que perdeu províncias. A atuação do homem de estado desempenha aí um papel pessoal na opção entre uma aspiração territorial (correr risco) e uma atitude de satisfação. Há ainda satisfação econômica: um país economicamente mais insatisfeito escolhe com mais freqüência líderes ambiciosos do que os satisfeitos e a insatisfação econômica é causa de perturbações e revoluções.

Em relação à questão "quando uma decisão é tomada", ela também coloca dificuldades ao historiador. Não se sabe quando se trata de realizar um objetivo ou de arranjar meios de atingir um outro objetivo, de natureza diferente. Mas 
para Duroselle, justamente porque o homem de estado ignora essa distinção entre fins e meios, o historiador tem dificuldade em distinguí-los.

Outro ponto importante sobre a tomada de decisão é a polêmica em se tentar estabelecer se uma decisão é racional ou irracional. O autor conclui que nas decisões de política externa a noção de racionalidade é relativa, pois a melhor decisão não é necessariamente aquela em que se procurou ser racional, e o essencial é ter bom êxito, sendo que para tal pode-se tê-lo por sorte, acaso, etc. e não agindo segundo cálculos matemáticos racionais (ele cita a teoria dos jogos), além do que, às vezes é preciso ousar e arriscar no momento da decisão, o que é tido como algo irracional.

Duroselle e Renouvin concluem que as diversas influências que orientam as Relações Internacionais (econômicas, psicológicas ou sentimentais e o papel dos homens de governo) se contrariam ou se associam segundo as condições diferentes, no tempo e no espaço. Por isso, o historiador ao procurar uma explicação deve examinar para cada caso o papel de cada uma dessas influências. Com isso constata-se que há, ora a influência dominante de forças econômicas ou demográficas (freqüentemente quando se estuda mudanças de longa duração), ora da força do sentimento e do espírito (sobretudo em crises internacionais em que intervêm paixões), ora das iniciativas individuais. Portanto, não se pode afirmar previamente que uma dessas forças foi predominante e nem isolar um dos aspectos do comportamento ou estabelecer uma hierarquia entre elas.

Assim, vê-se que para se afirmar que um presidente utilizou a diplomacia presidencial é preciso saber se ele foi o decisor final na questão e, como Duroselle apontou, isso não é fácil de ser identificado e muitas vezes até impossível.

As considerações finais, próximo e último capítulo desse trabalho, vão estabelecer uma relação dessa literatura internacional sobre a ação do 
presidente em política externa com a diplomacia presidencial, baseado na literatura brasileira que a abordou. Com isso se procurou esboçar se o conceito trouxe ou não inovação ao debate internacional já existente. 


\section{CAPÍTULO 4 - CoNSIDERAÇõES FINAIS}

A partir da análise da literatura de política externa, principalmente das análises sobre a diplomacia, que apesar do surgimento de novos atores, havia um consenso de que o Ministério das Relações Exteriores desempenhava um papel central. Mas a partir da década de 1990 alguns estudiosos começaram a destacar o papel de outros atores nesse processo, inclusive o da Presidência da República como o ator central. Essa discussão surgiu após a diplomacia presidencial ter maior visibilidade. O cenário de política externa havia mudado, com os presidentes brasileiros tendo uma atitude mais ativa na condução da política externa, o que levou alguns estudiosos a cunharem o termo de diplomacia presidencial. Uma questão a ser colocada nesse quadro é: foi o presidente quem mudou, tornando-se mais ativo, ou o Itamaraty, modernizando-se?

Antes porém de entrar nessa polêmica, vai-se recapitular os capítulos desse trabalho.

No capítulo 1 foram analisados dois atores considerados aqui como os principais em matéria de política externa: o presidente da República e o Itamaraty. Por esse motivo, parte-se do pressuposto que não se pode explicar o novo comportamento do presidente em política externa - a diplomacia presidencial - sem compreender-se o comportamento do Itamaraty.

Através da descrição das características de cada um desses dois atores e do contexto no qual o presidente e o MRE tomam as suas decisões de política externa, traçou-se um quadro. Foi nesse contexto que o conceito de diplomacia presidencial surgiu no Brasil. Para isso também foram abordadas algumas "crenças" sobre a política externa brasileira, que se referem a idéias já cristalizadas na literatura e que são importantes para a compreensão da política externa no Brasil e, concomitantemente, do novo comportamento do presidente da República nesse âmbito. Esse quadro forneceu indicações para elaborar-se uma possível explicação sobre a origem do termo, a ser discutida mais a frente desse capítulo. Aqui serão abordados somente os aspectos 
considerados mais importantes, visto que os outros já foram expostos no primeiro capítulo.

Primeiramente, para entender-se a diplomacia presidencial, partiu-se da análise das funções constitucionais do presidente da República, que derivam do regime de governo do país, que é o presidencialista. Porém o presidencialismo no Brasil tem suas especificidades, por isso foi chamado de "presidencialismo de coalizão".

Cerqueira (2005:53) aponta que as atribuições constitucionais da Presidência relacionadas à política externa são insuficientes para se caracterizar as ações de um presidente como diplomacia presidencial. Porque se isso fosse verdadeiro, Danese e Lafer não teriam como afirmar que Sarney e Cardoso foram expoentes da atuação de política externa comparados ao baixo perfil de Itamar e aos presidentes militares de 1964 a 1984. Ou seja, se essas responsabilidades em política externa atribuídas aos presidentes pela Constituição fossem o fator responsável pela diplomacia presidencial, todos os presidentes teriam exercido-a e não foi o que aconteceu. Conclui-se então que as atribuições constitucionais são mais um fator, dentre outros, que serão explorados nesse capítulo.

Uma das "crenças" sobre a política externa que foram abordadas e que é a mais importante a ser considerada é a da política externa como uma política de Estado. Nesse trabalho considera-se adequada à abordagem que interpreta a política externa como uma política pública e de governo e não como uma política específica - independente das outras políticas públicas e separada da política doméstica - e de Estado. A abordagem da política externa como uma política de governo deve levar em conta a conjuntura e também os diversos grupos de interesse existentes em torno de uma decisão. Estabelecendo agora uma relação entre política externa, política pública, opinião pública ${ }^{43}$ e diplomacia presidencial, pode-se dizer que com a diplomacia presidencial, a política exterior passou a ser de interesse não só da corporação diplomática,

\footnotetext{
${ }^{43}$ Sobre a relação entre presidente e opinião pública, conferir Foyle (1999).
} 
mas da sociedade como um todo. Assim, a diplomacia presidencial serviu como um instrumento capaz de dar a política externa o sentido de política pública (Cerqueira, 2005:54-5). Complementando essa linha de pensamento, pode-se afirmar também que o Itamaraty, pelas suas características institucionais, forneceu uma continuidade à política externa, que funcionava assim mais como uma política de estado. Com a diplomacia presidencial a política externa passou a funcionar como uma política de governo, uma política pública, com a incorporação de grupos heterogêneos no processo decisório de assuntos exteriores.

Dentre as características atribuídas ao MRE, também recorrentes na literatura, tem-se o consenso de que o Itamaraty desempenha o papel central em política externa (Altemani, 2005:23) e a sociedade brasileira aprova o papel do Itamaraty (Altemani, 2005:54; Holzhacker, 2005). Concorda-se com a segunda proposição. Porém, em relação à autonomia do Itamaraty considera-se que ela cedeu lugar a uma flexibilização desse órgão, que é a característica que merece mais destaque aqui. Isso vem acontecendo desde a década de 80 e é mais um elemento que compõe o contexto do surgimento da diplomacia presidencial, como será detalhado a seguir.

A partir da metade dos anos 80 ocorreram mudanças, nacionalmente e internacionalmente: o cenário internacional era do pós guerra-fria, com novos atores e temas; o que trouxe novos desafios à inserção internacional dos países. Somado a isso, tem-se o processo de democratização. A sociedade reagiu a essas mudanças organizando-se e mobilizando-se. O Itamaraty reagiu com a criação de canais de diálogo, consulta e participação da sociedade civil em temas de decisão específicos de política externa. Porém, o fez com a centralização e mantendo o controle sobre a agenda da política externa (Holzhacker, 2005:93).

Nesse contexto surge a diplomacia presidencial. A política externa em uma democracia e na era da globalização não se reduz às chancelarias. Ela abrange também atores diversos da sociedade: empresários, ONGs, etc. Isso abriu espaço para uma atuação mais autônoma da Presidência da República. A 
questão é se o fato de o presidente estar mais autônomo em política externa teve como conseqüência a diminuição do papel do Itamaraty ou não. Não há um consenso na literatura sobre isso. Para Guilhon Albuquerque (1996, 1997), Almeida (2004:5), Mourão (1996:9), Ayllón (2004) e Danese (1999) não houve uma diminuição do papel do Itamaraty. Para Cervo (1996) houve.

Para Guilhon Albuquerque (1996:10) a diplomacia presidencial não significa que a operação da diplomacia seja monitorada pelo Planalto ou que 0 Itamaraty receba instruções sobre objetivos e metas.

Almeida (2004a, 2004b:5) elaborou tabelas comparando a gestão Cardoso com a gestão Lula e em relação aos instrumentos diplomáticos, ele observou que no governo Cardoso o Itamaraty era o foco principal (sendo que os conselheiros presidenciais eram diplomatas) e havia o que ele nomeou como uma "diplomacia presidencial explícita". Por outro lado, no governo Lula o Itamaraty é um dos focos, ou seja, "partilha a formulação e até mesmo a execução da política externa com assessores presidenciais". Assim, o autor afirma que o presidente Lula exerce uma diplomacia presidencial também explícita, mas que, pelo fato do conceito ter sido recusado por essa gestão, devido a sua suposta identificação com a administração Cardoso, o autor a identifica como uma "diplomacia presidencial implícita". Sem entrar em comparações com as duas gestões, vê-se que tanto em uma como na outra gestão, para Almeida o MRE conviveu com a Presidência e não houve uma diminuição de seu papel.

Para Mourão (1996:9), o presidente Cardoso lançou a idéia da diplomacia presidencial e não tinha intenção de transferir as práticas diplomáticas para o Planalto, mas sim salientar que a diplomacia no atual momento histórico do Brasil, induz a "uma maior concatenação do Estado a um tema que, tradicionalmente, era de domínio exclusivo do Itamaraty...".

Já para Cervo (1996:8), diferentemente dos autores acima mencionados, houve uma diminuição do papel do Itamaraty em política externa com a diplomacia presidencial: "A política externa passou a fazer-se com diplomacia pessoal, deprimindo-se o papel do Itamaraty". 
Lima (1994:32-3) tem uma tese diferente, para ela "... no presidencialismo brasileiro o parâmetro que regula os graus de liberdade ou autonomia relativa retida pela diplomacia é a autorização presidencial, seja por omissão ou delegação de poder - como nos governos Médici (em algumas áreas de política externa) e Figueiredo - ou por afinidade de pontos de vista, como nos casos do governo Geisel e Sarney."

Ayllón (2004:382) afirma que as viagens presidenciais e a participação do presidente em conferências e reuniões de cúpula internacionais (modalidade de diplomacia presidencial) são mais um instrumento diplomático que a diplomacia brasileira pode utilizar - a partir de 1995 - para promover os interesses do país no exterior. Assim, a diplomacia presidencial não substitui a diplomacia tradicional, mas a complementa, como afirma Danese. Para esse autor, o mandatário precisa da chancelaria, que realiza um trabalho de preparação e seguimento da atividade de cúpula. Para Danese (1999:109) a diplomacia tradicional não se retraiu com a diplomacia presidencial. $O$ que houve foi apenas uma queda da visibilidade da diplomacia tradicional com o aumento da visibilidade da Presidência.

Até aqui foi exposto o cenário que propiciou o surgimento da diplomacia presidencial: um presidencialismo forte e uma mudança no contexto de política externa, com a guerra fria internacionalmente e a redemocratização nacionalmente, propiciando a flexibilização do Itamaraty e a entrada de novos atores na atuação de política externa. Ainda que o MRE mantenha o controle da agenda, na maioria dos casos prevalecem dois atores no processo de decisório: o MRE e o presidente.

Com o intuito de analisar a diplomacia presidencial conceitualmente, foram trabalhados no capítulo 2 as publicações que abordaram a temática e quais definiram o conceito. Isso contribui para a compreensão do estatuto teórico da diplomacia presidencial, ainda indefinido. 
O único trabalho com preocupação conceitual é sem dúvida o de Danese. Os outros analisaram a diplomacia presidencial enquanto prática políticodiplomática e não enquanto conceito. Apesar de poucos terem elaborado uma definição, no decorrer do texto, eles dão indícios de como a interpretaram. Com isso foi elaborado neste presente trabalho um quadro da literatura que abordou o tema ${ }^{44}$. Podemos concluir quando a diplomacia presidencial se tornou recorrente nos debates tanto na mídia quanto acadêmicos: esse tema se tornou comum nas análises de política externa a partir da gestão Cardoso.

Ainda com o intuito de contribuir para o estatuto teórico do termo, analisou-se nesse mesmo capítulo as críticas que os autores colocaram em relação à diplomacia presidencial. Danese criticou a banalização da utilização da diplomacia de cúpula, resultado de seu uso intenso e às vezes desnecessário na atualidade. Criticou ainda o fato da diplomacia presidencial brasileira ser muito personalista, ou seja, ser muito dependente do perfil pessoal do presidente. Segundo o autor, isso contribui para a opinião pública ter uma visão pessimista da diplomacia presidencial, como algo passageiro, e não ligada a mecanismos institucionais. Além disso, Danese também criticou o fato de que a diplomacia presidencial submeteu a burocracia diplomática a um esforço do qual ela não estava preparada.

O autor também elaborou avaliações positivas à diplomacia presidencial. Segundo Danese, ela recolocou o Brasil no mapa da diplomacia de cúpula mundial e ampliou o debate de política externa na opinião pública.

O uso intenso da diplomacia presidencial na atualidade é apontado por muitos autores como a grande novidade sobre a temática. Antes a condução de certas áreas, temas e situações da diplomacia era feita normalmente pelos chanceleres.

Danese, assim como Guilhon Albuquerque, faz uma ressalva quanto ao uso desse termo como sinônimo de 'viagens presidenciais'. Segundo Guilhon

\footnotetext{
${ }^{44}$ Conferir p. 53 dessa dissertação.
} 
Albuquerque é comum confundir a agenda pessoal do presidente com a diplomacia presidencial. Para ele isto não procede, pois a agenda pessoal é criada para o presidente e ele não tem necessariamente autonomia nas decisões de política externa. As viagens podem ser simplesmente protocolares e não significarem nenhuma intervenção direta e autônoma do presidente em algum tema ou acordo internacional. Assim, vê-se, inclusive em muitos artigos, o uso pouco criterioso do termo diplomacia presidencial, que ainda carece de mais elementos para poder ser bem aplicado.

Danese argumenta que só é possível afirmar que um presidente faz uso da diplomacia presidencial a partir de uma análise aprofundada da situação em questão. Acredita-se também que em muitos casos - quando há dificuldade de acesso ao material oficial e às informações - não será possível fazê-lo.

Até aqui se viu críticas à prática da diplomacia presidencial e a aplicabilidade do conceito na prática, mas em relação às críticas ao conceito em si, somente Guilhon Albuquerque o fez. Para ele a "decantada 'diplomacia presidencial' " ainda não tem uma definição precisa e por isso ele é cético quanto à aplicabilidade desse conceito na política externa brasileira. A crítica do autor recai no emprego generalizado do termo diplomacia presidencial, utilizado por muitos sem maiores reflexões.

No capítulo 3 o objetivo foi analisar o conceito de diplomacia presidencial dentro da discussão já existente sobre política externa na literatura internacional, especificamente na sua análise sobre a ação do presidente da República em assuntos externos, para então apreender o que esse conceito trouxe de novo ao debate já existente ou se não inovou. Esse discussão se refere a literatura internacional, que incorporou a análise do presidente em política externa há mais tempo que a nossa literatura. Vai-se estabeler uma comparação a partir de cada teoria exposta no capítulo 3 , começando por Allison.

O modelo 3 de Allison se aproxima da diplomacia presidencial no que concerne à abordagem da política externa como política pública. Para a abordagem da 
diplomacia presidencial a política externa funciona como uma política de governo, uma política pública, com suas mudanças e incorporação de grupos heterogêneos no processo decisório de assuntos exteriores, assim como para o modelo de política burocrática. Fora esse aspecto de aproximação, a diplomacia presidencial inova o debate em relação ao estudo de Allison, pois em nenhum dos seus 3 modelos ele aborda elementos que poderiam apontar essa atitude autônoma do presidente em política externa. Segundo o modelo 1 , o presidente poderia ser esse ator racional e unitário no processo de política externa, mas a diplomacia presidencial engloba um cenário de convivência com mais atores, que corresponderia ao modelo 3. Porém o modelo de política burocrática, pressupõe um jogo de barganha e, se assim o fosse, o presidente não seria autônomo na política externa, como supõe a diplomacia presidencial. Quanto ao modelo 2, ele implica um líder que só influencia e não decide, o que exclui automaticamente a diplomacia presidencial.

M. e C. Hermann elaboraram a categoria de unidade de decisão final, que por sua vez tem 3 tipos, sendo que o tipo líder predominante é o que interessa nessa pesquisa, pois se aproxima da categoria diplomacia presidencial. Segundo os autores (1989:362-3) a unidade de decisão final identifica, decide e implementa a política externa, representa o decision-maker, mas não qualquer decisor. Somente aqueles que possuem duas características específicas: a habilidade de comprometer os recursos do governo em assuntos externos e 0 poder ou autoridade para prevenir outras entidades do governo de reverter sua posição, sem custos significativos. Assim, em uma questão pode haver vários atores com capacidade de decisão, vários decisores, mas somente um será a unidade de decisão final (seja ele uma pessoa ou um grupo). Quando um presidente faz uso da diplomacia presidencial, diz-se que ele é, no caso, a unidade de decisão final (Danese, 1999:394). Concluí-se a partir dos Hermann que a categoria diplomacia presidencial não inovou o debate, pois o próprio Danese (1999:394) notou que quando um presidente faz uso da diplomacia presidencial ele é a unidade de decisão final no processo de política externa, assim, ele utilizou a expressão de M. e C. Hermann para complementar a sua conceituação. 
Para George, a primeira tarefa de um novo presidente é definir o seu próprio papel no sistema de formulação de política externa e estruturar e gerenciar o papel dos outros atores envolvidos nesse sistema e suas relações. Isso implica em decidir se ele, presidente, dará o papel principal em assuntos de política externa ao secretário de estado, que no Brasil corresponde ao ministro das relações exteriores ou se centralizará e gerenciará esses assuntos ele mesmo, ou ainda se optará por um sistema relativamente descentralizado, que seria coordenado por ele e seu assistente especial de assuntos de segurança nacional. Pode-se traçar aqui um paralelo com a diplomacia presidencial, que poderia então ser definida como um caso específico do papel da Presidência frente ao staff de política externa. Ela ocorreria quando o presidente optasse por coordenar o policy-making process centralizando e gerenciando os assuntos ele mesmo, para utilizar a concepção de George. Então, até aqui o conceito de diplomacia presidencial também não trouxe nenhuma novidade nessa discussão.

Para Duroselle a resposta à questão "quem tomou a decisão" não é fácil. A estrutura jurídica permite identificar a autoridade responsável, por exemplo nos regimes parlamentares é o conselho de ministros e no regime presidencialista, dos EUA por exemplo, é o presidente, já numa ditadura pessoal, é o próprio ditador. Mas geralmente têm-se poucos meios de sabe quem foi o responsável efetivo, a autoridade responsável pode delegar quase todos os seus poderes de política externa a um subordinado. De outro lado, pelo menos nos regimes fracos, um subordinado pode tomar uma iniciativa. O autor aponta (1965:440-1) também que toda decisão implica riscos e no cálculo do risco pode-se cometer erros. Quem geralmente irá decidir se correrá ou não este risco é o homem de estado, o que pode depender de seu temperamento e de outros fatores também, como por exemplo se o país é satisfeito ou insatisfeito. Assim, vê-se que para se afirmar que um presidente utilizou a diplomacia presidencial é preciso saber se ele foi o decisor final na questão e, como Duroselle apontou, isso não é fácil de ser identificado e muitas vezes até impossível.

Duroselle e Renouvin constatam que há ora a influência dominante de forças econômicas ou demográficas (freqüentemente quando se estuda mudanças de 
longa duração) na orientação das Relações Internacionais, ora da força do sentimento e do espírito (sobretudo em crises internacionais em que intervem paixões), ora o papel determinante é o das iniciativas individuais. Poderíamos afirmar que esse último caso corresponde à diplomacia presidencial. Parece que aqui também já se abordava de algum modo a diplomacia presidencial, sem nomeá-la.

Analisando a literatura internacional vê-se que o surgimento do conceito de diplomacia presidencial foi inovador no sentido de nomear a atitude mais ativa do presidente em política externa. Ou seja, as características do conceito estavam implícitas, já eram abordadas nessas teorias (aqui se faz exceção à Allison, onde houve inovação, já que não apontou tais características). Porém, não se encontravam abaixo do rótulo de um só conceito, além de estarem diluídas em várias teorias e não em uma só. Por outro lado, o surgimento do conceito de diplomacia presidencial não foi inovador justamente porque 0 ativismo presidencial já havia sido apontado na literatura internacional, somente sem a intitulação.

Foram apontadas aqui não respostas, mas algumas hipóteses sobre o conceito de diplomacia presidencial. A primeira é que ela pode ser conseqüência de uma flexibilização do Itamaraty, com uma diminuição do poder decisório desse órgão, que assim abriu espaço para uma atuação mais forte da Presidência da República. Uma outra hipótese é que a diplomacia presidencial é uma exigência da globalização e do mundo em blocos, e assim, tanto Itamaraty quanto a Presidência concordam com o seu uso como mais um instrumento diplomático, não representando perda de poder de nenhum deles. Uma outra hipótese ainda seria a de que a diplomacia presidencial é mais importante nas conseqüências políticas que traz do que nas teóricas. Desse modo, Danese apontou (1999:52) que "diplomacia de cúpula não é um conceito teórico; é uma realidade muito concreta das relações internacionais... é preciso vê-la em ação, com suas vantagens e vicissitudes, para compreendê-la bem."

Para responder a essas hipóteses seria necessário um trabalho mais denso e mais demorado, proposta de um doutorado. Aqui elas ficam apenas indicadas. 
Já colocadas às hipóteses e questões que ficaram sem resposta, faz-se agora um balanço do que se pode afirmar com esse trabalho. Em relação à aplicabilidade do conceito na prática da política externa, pode-se afirmar que é algo difícil de se fazer, pois o conceito permanece até então relativamente indefinido. Há necessidade de mais pesquisas - principalmente de caráter empírico para se poder testá-lo e assim fazer-se afirmações mais consistentes sobre o seu uso como um instrumental. Conclui-se também que a diplomacia presidencial enquanto conceito ainda é inconsistente, pois como foi dito, não existe ainda uma discussão teórica sobre o tema, com exceção do livro de Danese. Todos os outros autores que a abordaram praticamente concordam com Danese no aspecto conceitual, única exceção é Guilhon Albuquerque, para o qual o termo é ainda indefinido e portanto pouco criterioso e por isso esse autor resiste em utilizá-lo. Ou outros autores estabeleceram críticas em relação à diplomacia presidencial, mas enquanto prática político-diplomática e não enquanto conceito.

Conclui-se também que apesar do termo ainda carecer de um estatuto teórico mais definido, ele apontou para uma mudança na prática diplomática, que por sua vez exigiu um termo novo para descrevê-la, já que a literatura usual apontava a autonomia do Itamaraty, mais do que a sua abertura; literatura essa que ainda estava se formando no Brasil, mas que não havia, mesmo assim, incorporado a figura do presidente com esse papel mais autônomo em assuntos externos. Viu-se que a literatura internacional já apontava características de um presidente mais autônomo em política externa, mas ela não nomeava essa nova atitude do presidente, donde se poderia afirmar que a diplomacia presidencial surgiu para descrever essa nova situação.

Rosenau aponta (1987: 2-3) que o mundo se tornou interdependente e com isso as fontes e conseqüências da política externa também, com o surgimento de novos problemas teóricos e metodológicos e exigindo dos seus estudiosos que aperfeiçoem suas ferramentas analíticas. Uma hipótese é que o conceito de diplomacia presidencial tenha surgido com esse propósito, como uma ferramenta, um instrumental que tentaria explicar a nova realidade. 
Essa nova realidade foi uma atuação mais ativa do presidente em política externa. Algo que vinha ocorrendo desde a redemocratização, mas que com o presidente Cardoso assumiu um tom diferente, porque ele tinha um projeto político de política externa, tinha objetivos para política externa que não vinham da corporação diplomática e isso gerou uma grande visibilidade da diplomacia presidencial para a sociedade em geral.

Ayllón e Danese comentaram sobre o presidente ter seus objetivos de política externa, ter seu projeto diplomático. Para Ayllón (2005:382) há uma estreita relação entre o projeto político interno do presidente Cardoso e seu projeto diplomático e Danese também se refere a isso em vários momentos no seu livro. Para esse autor (1999:85) a política externa é um dos espaços no qual o líder age dentro de seu projeto pessoal e o mandatário realiza as visitas internacionais segundo o seu interesse pessoal e o projeto diplomático do seu governo e país. Mas Danese complementa (1999:101) que não pode haver diplomacia de cúpula desvinculada do projeto diplomático do país, como um projeto estritamente pessoal do mandatário, e aí está o perigo de uma diplomacia presidencial pouco institucionalizada, como apontou anteriormente o autor.

Assim, o que se objetivou com esse trabalho foi analisar o conceito de diplomacia presidencial dentro da discussão já existente sobre política externa, para então apreender o que esse conceito trouxe de novo a esse debate ou se não inovou. Indiretamente também se abordou a dificuldade de utilizá-lo como um instrumental, já que ainda se encontra relativamente indefinido.

A esperança é que esse trabalho tenha contribuído ao menos um pouco para o esclarecimento da diplomacia presidencial, de uso tão freqüente, mas com pouca reflexão sobre seu aspecto conceitual. 


\section{REFERÊNCIAS BIBLIOGRÁFICAS}

Abranches, Sérgio Henrique H. "O presidencialismo de Coalizão: o dilema institucional brasileiro". Dados, Rio de Janeiro, v. 31, n.1, p. 5-33, 1988.

Allison, Graham T. "Conceptual models and the Cuban missile crisis". The American Political Science Review, v. 63, n. 3, p. 689-718, Sept. 1969.

Almeida, Paulo Roberto de. "Uma política externa engajada: a diplomacia do governo Lula". Revista Brasileira de Política Internacional, Brasília, ano 47, n. 1, 2004a.

"A estratégia de integração internacional do Brasil: mudanças recentes". In: III Semana de Economia da Unicamp-Instituto de Economia, 2004b, Campinas. (23 de setembro).

Altemani de Oliveira, Henrique. Política externa brasileira. São Paulo: Saraiva, 2005.

Amorim, Celso L. N. "Uma diplomacia voltada para o desenvolvimento e a democracia". In: Fonseca Jr., Gelson; Nabuco de Castro, Sérgio Henrique (Org.). Temas de política externa brasileira II. São Paulo: Paz e Terra, 1997, v. 1 , p. $15-29$.

Arbilla, José Maria. A diplomacia das idéias: a política de renovação conceitual da política externa na Argentina e no Brasil (1989-1994). Rio de Janeiro, 1997. Dissertação (Mestrado em Relações Internacionais) - Instituto de Relações Internacionais, Pontifícia Universidade Católica do Rio de Janeiro.

"Arranjos Institucionais e Mudança Conceitual nas Políticas Externas Argentina e Brasileira". Contexto Internacional, v. 22, n. 2, p. 337-385, 2000.

Arenal, Celestino de. Introducción a las relaciones internacionales. Madrid: Tecnos, 2002.

Ayllón Pino, Bruno. "Entre presidentes está el juego...diplomático". 3 f. Mimeo. Danese, Sérgio. Diplomacia presidencial: história e crítica. Rio de Janeiro: Top Books, 1999.

Las relaciones entre Brasil y Espana ponderadas desde la perspectiva de la política exterior brasileña (1979-2000). Madrid, 2004. Tesis Doctoral - Facultad de Ciências Políticas y Sociología, Departamento de Derecho Internacional Público y Relaciones Internacionales, Universidad Complutense de Madrid.

Baptista, Olavo Luiz. "As cores da conjuntura internacional". Panorama da conjuntura internacional. Gacint/USP, ano 6, n. 21, p. 10-1, maio/jun. 2004. 
Barros, Alexandre de S. C. "A formulação e implementação da política externa brasileira: o Itamaraty e os Novos Atores". In: Muñoz, Heraldo; Tulchin, Joseph S. (Org.). A América Latina e a Política Mundial. São Paulo: Convívio, 1986, p. 29-41.

Boito Jr., Armando (Org.). Parlamentarismo e presidencialismo: a teoria e a situação brasileira. Rio de Janeiro: Paz e Terra, 1993.

Brasil, Constituição (1988). Constituição da República Federativa do Brasil. São Paulo: Melhoramentos, 1988. (Encyclopaedia Britannica do Brasil).

Carvalho Vieira, Marco A. M. de. "Idéias e instituições: uma reflexão sobre a política externa brasileira do início da década de 90". Contexto Internacional, Rio de Janeiro: IRI/PUC, v. 23, n. 2, p. 245-293, jul./dez. 2001.

Cerqueira, Rodrigo. Diários do Príncipe - Imprensa e política externa no governo Cardoso (1995-2002). Rio de Janeiro, 2005. Dissertação (Mestrado em Relações Internacionais) - Instituto de Relações Internacionais, Pontifícia Universidade Católica do Rio de Janeiro.

Cervo, Amado Luiz. "Diplomacia Presidencial cultiva parcerias estratégicas". Carta Internacional, n. 35, p. 8, jan. 1996.

Cheibub, Zairo. "Diplomacia e Construção Institucional: O Itamaraty em Perspectiva Histórica". Dados, v. 28, n. 1, p. 113-131, 1985.

Coimbra, Márcio C. "Diplomacia Presidencial". Meridiano 47, Brasília, IBRI, n. 22, , p. 14-5, maio 2002.

Danese, Sérgio. Diplomacia presidencial: história e crítica. Rio de Janeiro: Top Books, 1999.

"Dez pontos para uma política externa de consenso". Carta Internacional, ano X, n. 115, p. 7-11, set. 2002.

Duroselle, Jean-Baptiste. "Segunda Parte: O Homem de Estado". In: Renouvin, Pierre; Duroselle, Jean-Baptiste. Introdução à História das Relações Internacionais. Trad. Hélio de Souza. São Paulo: Difusão Européia do Livro, 1967, p. 301-480.

Fernandes, Luis. "Fundamentos y desafíos de la política exterior del Gobierno Lula". Revista Cidob d'afers Internacionals, n. 65, s.p., mayo/jun. 2004.

Fernandes de Oliveira, Marcelo. Negociações comerciais internacionais e democracia no Brasil: contenciosos das patentes, do algodão e do açúcar na OMC. São Paulo, 2005. Tese (Doutorado em Ciência Política) - Faculdade de Filosofia, Letras e Ciências Humanas, Universidade de São Paulo.

Foyle, Douglas C. Counting the Public in: Presidentes, Public Opinion, and Foreign Policy. New York: Columbia University Press, 1999. 
Genoíno, José. "O declínio da diplomacia presidencial". Carta Internacional, ano VI, n. 71, p. 7, jan. 1999.

George, Alexander L. "The president and the management of foreign policy: styles and models". In: Kegley Jr., Charles W.; Wittkopf, Eugene R. (Ed.). The domestic sources of American foreign policy - insights and evidence. New York: St. Martin's Press, 1988, p. 107-126.

Guilhon Albuquerque, José Augusto. "A Presidência na linha de frente da diplomacia”. Carta Internacional, n. 35, p. 10, jan. 1996.

"O alcance da 'diplomacia

presidencial'”. Carta Internacional, n. 47, p. 8, jan. 1997.

Hermann, Margaret G.; Hermann, Charles F. "Who makes foreign policy decisions and how: an empirical inquiry". International Studies Quartely, n. 33, p. 361-187, 1989.

Hermann, Margaret G. "The role of leaders and leadership in the making of american foreign policy". In: Kegley Jr., Charles W.; Wittkopf, Eugene R. (Ed.). The domestic sources of American foreign policy - insights and evidence. New York: St. Martin's Press, 1988, p. 266-284.

Holsti, Ole R. "Modelos de relaciones internacionales y política exterior". Revista Foro Internacional, México, v. XXIX, n. 4, p. 525-560, abr./jun. 1989.

Holzhacker, Denilde Oliveira. Atitudes e percepções das elites e da população em geral sobre a política externa brasileira nos anos 90. São Paulo, 2005. Tese (Doutorado em Ciência Política) - Faculdade de Filosofia, Letras e Ciências Humanas, Universidade de São Paulo.

Houaiss, Antônio e Villar, Mauro de Salles (Ed.). Dicionário Houaiss da Língua Portuguesa. Rio de janeiro: Objetiva, 2004.

Lafer, Celso. Mudam-se os tempos: diplomacia brasileira - 2001-2002. Brasília, DF: FUNAG/IPRI, 2002.

- "Brasil: dilemas e desafios da política externa". Revista de Estudos Avançados, v. 38, n. 14, p. 260-267, jan./abr. 2000.

Lima, Maria Regina Soares de. "Ejes analíticos y conflicto de paradigmas em la política exterior brasileña". América Latina/Internacional, Argentina: FLACSO, v. 1, n. 2, p. 27-46, otoño-invierno 1994.

diplomática". Carta Internacional, n. 35, p. 5-6, 1996. "Política doméstica determina atuação 
Lima, Maria Regina Soares de. "Instituições Democráticas e Política Exterior". Contexto Internacional, Rio de Janeiro: IRI/PUC, v. 22, n. 2, p. 265-303, jul./dez. 2000.

Linz, Juan. "Presidencialismo ou parlamentarismo: faz alguma diferença". In: Lamounier, Bolívar (Org.). A opção parlamentarista. São Paulo: IDESP: Sumaré, 1991, p.61-120.

Malamud, Andrés. "O Presidencialismo na América do Sul: Argentina e Brasil em Perspectiva Comparada". Análise Social, Lisboa: Instituto de Ciências Sociais da Universidade de Lisboa, v. XXXVIII, n. 168, p. 715-742, 2003.

. "Presidential Diplomacy and the Institutional Underpinnings of Mercosur: An Empirical Examination?" Latin American Research Review, v. 40, n. 1, p. 138-164, 2005.

Presidenciales), ago. 2005b.

"Presentación". América Latina Hoy. n. 40 (Cumbres

Disponível em: <http://iberoame.usal.es/publicaciones/americalatinahoy/>.

. (forthcoming) "Jefes de gobierno y procesos de integración

regional: las experiencias de Europa y América Latina". In: Briceño Ruiz, José; and Kochi, Shigeru (Ed.). Nuevas dimensiones y estrategias de integracion en el Continente Americano: Del regionalismo latinoamericano a la integración interregional.

Disponível

em:

<http://www.iue.it/Personal/Researchers/malamud/Abstracts.html\#Other>.

Malamud, Carlos. "Las cumbres iberoamericanas en el actual escenario mundial". In: Arenal, Celestino del (Coord.). Las cumbres iberoamericanas (1991-2005) - logros y desafíos. Madrid: Siglo, 2005, p. 27-45.

Melissen, Jan. "Summit Diplomacy coming of age". Discussion papers in diplomacy. Netherlands Institute of International Relations 'Clingendael', 2003. Disponível

em: $<$ http://www.clingendael.nl/publications/2003/20030500_cli_paper_dip_issue86. pdf $>$.

Mello, Flavia de Campos. Regionalismo e inserção internacional. Continuidade e transformação da política externa brasileira nos anos 90. São Paulo, 2005. Tese (Doutorado em Ciência Política) - Faculdade de Filosofia, Letras e Ciências Humanas, Universidade de São Paulo.

Mello e Silva, Alexandra de. "Idéias e política externa: a atuação brasileira na Liga das Nações e na ONU". Revista Brasileira de Política Internacional, v. 2, n. 41, p.139-158, 1998.

MRE - Ministério das Relações Exteriores. Disponível em: $<$ http://www.mre.gov.br>. 
Mourão, Fernando Albuquerque. "Inserção internacional pede atuação multilateral". Carta Internacional, n. 35, p. 9, jan. 1996.

Núñez, Alberto de. "La diplomacia presidencial." Archivos del Presente, Buenos Aires, año 3, n. 10, p. 133-139, oct.-dic. 1997.

Onuki, Janina. "Considerações sobre a diplomacia presidencial brasileira". Carta Internacional, ano 8, n. 83, p. 11, jan. 2000. Resenha de: Danese, Sérgio. Diplomacia presidencial: história e crítica. Rio de Janeiro: Top Books, 1999.

As mudanças da política externa argentina no governo Menem (1989-1999). São Paulo, 2002. Tese (Doutorado em Ciência Política) Faculdade de Filosofia, Letras e Ciências Humanas, Universidade de São Paulo.

Ostellino, Piero. "Diplomacia". In: Bobbio, Norberto; Matteucci, Nicola; Pasquino, Gianfranco. Dicionário de Política. 5. ed. Trad. Carmem C. Varrialle et al. Brasília: Unb; São Paulo: Imprensa Oficial, 2004. v. 1, p. 348-9.

Peña, Félix. "La Compleja red de cumbres presidenciales: Reflexiones sobre el sentido y la eficacia de la diplomacia presidencial multilateral y multi-espacial en el caso de los países sudamericanos. Su dimensión económica". América Latina Hoy, n. 40 (Cumbres Presidenciales), ago. 2005.

Disponível em: <http://www.fundacionbankboston.com.ar/inst/sec10/docsfelixpena/articulos/2005-03-am-lat-hoy.doc>.

Pinheiro, Letícia. "Unidades de decisão e processo de formulação de política externa durante o regime militar". In: Guilhon Albuquerque, J. A. (Org.). Sessenta anos de política externa brasileira 1930-1990. São Paulo: Annablume/NUPRI/USP, 2000, p. 449-474. (Coleção Sessenta anos de política externa brasileira (1930-1990); v. 4).

Política Externa Brasileira. Rio de Janeiro: Jorge Zahar, 2004. (Coleção Descobrindo o Brasil).

Pistone, Sergio. "Relações Internacionais". In: Bobbio, Norberto; Matteucci, Nicola; Pasquino, Gianfranco. Dicionário de Política. 5. ed. Trad. Carmem C. Varrialle et al. Brasília: Unb; São Paulo: Imprensa Oficial, 2004. v. 2, p.1089.

Renouvin, Pierre; Duroselle, Jean-Baptiste. Introdução à História das Relações Internacionais. Trad. Hélio de Souza. São Paulo: Difusão Européia do Livro, 1967.

Rojas Aravena, Francisco \& Milet García, Paz. "Diplomacia de cúpulas: O Multilateralismo Emergente do Século XXI". Contexto Internacional, Rio de Janeiro: IRI/PUC, v. 21, n. 2, p. 291-359, jul./dez. 1999. 
Rojas Avarena, Francisco."Las cumbres iberoamericanas y los retos de la diplomacia de cumbres". In: Arenal, Celestino del (Coord.). Las cumbres iberoamericanas (1991-2005) - logros y desafíos. Madrid: Siglo, 2005, p. 47-71.

Roque, Atila P. "A política externa no governo Cardoso". In: A era FHC e o Governo Lula: transição? Rocha, Denise; Bernardo, Maristela (Org.). Brasília: Instituto de Estudos Sócio-econômicos, 2004, p. 449-472. Disponível em: $<$ http://www.inesc.org.br/conteudo/publicacoes/livros/4GW7inLLkRaDio1vtL3RpN4400Jj5lxZ/P ol\%EDtica\%20externa.pdf>.

Rosenau, James. "Introduction: new directions and recurrent questions in the comparative study of foreign policy". In: Hermann, C. F.; Kegley Jr., C. W.; Rosenau, J. N. (Ed.). New Directions in the study of foreign policy. Boston: Allen \& Unwin, 1987, p.1-10.

Sales, Camila Maria Risso. "Relações internacionais e política externa do Brasil nos governos e FHC e Lula: uma análise paradigmática". In: IV Simpósio de Ciência Política do DCP/USP, 2006, São Paulo (mesa 2: Política Externa Brasileira, 18 de março).

Seitenfus, Ricardo. Para uma nova política externa brasileira. Porto Alegre: Livraria do Advogado Ed., 1994.

Schlesinger, Jr. Arthur M. "The presidency and the imperial temptation". In: Kegley Jr., Charles W.; Wittkopf, Eugene R. (Ed.). The domestic sources of American foreign policy - insights and evidence. New York: St. Martin's Press, 1988, p. 127-130.

Sol Arriaza, Ricardo; Cardona, Rockael; Solís, Luis Guillermo. La Agenda programática de la OEA a la luz de las cumbres Presidenciales: una mirada desde la sociedad civil. San José (Costa Rica): FUNPAPEM / CRIES, 2004. Disponível em: <www.cries.org/boletin/QUEBEC.pdf>

Tomassini, Luciano. Teoria y practica de la política internacional. Chile: Ediciones Universidad Católica de Chile, 1989.

Vigevani, Tullo; Fernandes de Oliveira, Marcelo. "A política externa brasileira na era FHC: um exercício de autonomia pela Integração". 4 Encontro Nacional da ABCP - Associação Brasileira de Ciência Política, 2004, Rio de Janeiro. (Área Relações Internacionais, Painel (4) Política Externa Brasileira, 21-24 julho PUC). 